


\section{ON THE NORTH AMERICAN SPECIES OF THE GENUS ATAX (FABR.) BRUZ.}

\section{ROBER'T H. WOLCO'TT.}

\section{GENERAL CONSIDERATIONS.}

One who opens many of our fresh-water mussels, cannot fail to notice, in part of them at least, dark spots upon the mantle or gills, which a moment's observation will show are living, moving organisms. A lens will reveal the fact that they have four pairs of six-jointed legs and a pair of five-jointed palpi, but no antennæ-like structures, that the head, thorax and abdomen are fused into one mass with no trace of segmentation, and that the relatively long legs are clothed with spines and hairs which assist in swimming. Two small blackish or brownish eyes may be detected near the anterior margin. These characters point to the taxonomic position of these creatures in the order Acarina or Mites and in the family Hydrachnidæ or WaterMites, while their presence in the mussel suggests their membership in the genus Atax, the members of which are musselparasites, during at least a part of their existence. Rarely representatives of other non-parasitic genera may be found within these shells, but their occurrence there is purely accidental; on the other hand few species of this genus are found except in mussels. However, the genus is not confined to the Unionidæ, a single species having been found in the mantle-cavity of a South American gasteropod, Ampullaria, related to our genus Campeloma, and the author having detected another previously described species in a species of Sphceriun, one of the Cyrenidæ.

In scanning the literature on the subject we discover but scattered references to Hydrachnidæ, under the generic term Acarus, previous to 1781 , when O. F. Miiller described 49 species from Denmark, establishing for them the new genns 
Hydrachna. In 1793, J. C. Fabricius included all these under Trombidium, but in 1805 he established the genus Atax which was equivalent to Hydrachna of Müller. Previously, in 1796, P. A. Latreille had erected the genera Limnochares and Eylais, but these were by Fabricius included under Atax. In 1834, Antoine Dugès restricted the name Iydrachna to a few species which are still so classified, re-established the genera Limnochares and Eylais, and separated from Atax Fabricius, which included the greater number of the species, the additional genera Diplodontus and Arrenurus. In 1837 the genus of Fabricius was still more sharply limited by C. L. Koch, who separated several new genera; but only in 1854 and by Ragnar Bruzelius was the genus Atax reduced to the limits which were for forty years accepted by all students of the group as its natural bounds and are by many still so regarded. In 1894 Richard Piersig, on grounds considered insufficient by Koenike, separated from Atax the genus Cochleophorus, and in the past year, 1897, he has proposed another new genus, Encentridophom, to inchude a species described by Koenike from East Africa, and the genus Najadicola to include one of our American species, also described by Koenike. The characters which separate Cochleophoms from Atax, as thus limited, are sufficient, it seems to the author, to render the former a valid genus; certainly the two designate clearly defined groups of species and all described forms fall naturally into one or the other of these groups. In accordance with this view the species included under Cochleoploris are excluded from this paper. In regard to Najadicola, however, while it possesses certain characters which differ from those of other species of parasitic mites, the writer has been unable to agree with Piersig in thinking these differences such as to entitle it to more than sub-generic rank.

As in the above manner limited, the characters of the genus Atax are thus defined by Piersig in his "Deutschlands $\mathrm{Hy}$ drachniden" (97):

Body soft, with but a slight tendency to the formation of chitinous thickenings over the surface, round or oval; on the 
anterior margin no concavity; the posterior margin evenly rounded or with a shallow median concavity. The first pair of legs distinguished by an unusual thickness and in the nollparasitic species provided with long, stout, movable, swordshaped spines, inserted into prominently projecting papillæ. Second pair usually exceeding the third in length. The proportion between the length of the body and legs quite variable, but generally the legs of the parasitic species shorter than those of the non-parasitic. The maxillary shield is not fused with the neighboring epimera. In ventral view it resembles in shape a broad chalice. The palpi are long; in the parasitic forms they equal or exceed in thickness the first pair of legs. The next to the last segment possesses on its ventral side three papillæ varying in size in different species; of these the one at the outer end ends in a chitinous spur, while the two others placed somewhat farther posteriorly are each crowned with a little hair. The fifth palpal segment is short and provided with chitinous claws. Among the epimera those of the fourth pair are distinguished by their size and more or less rectangular form. Third epimeron imperfectly separated from the fourth. Genital area at the extreme end of the body. The chitinous plates surrounding the genital cleft from either side, bear together 10, 12, or numerous, acetabula. In the females characteristic sword-like spines appear in the vicinity of the genital opening, which are employed in oviposition.

This diagnosis is not strictly applicable to all of our species, even excluding Atax (Najadicola) ingens (Koenike), since both A. abnormipes mihi and $A$. indistinctus mihi are deeply emarginate posteriorly, $A$. pectinatus mihi is a non-parasitic form yet lacks the movable spines on the first pair of legs, and the genital area is not ill all forms at the extreme end of the body, though usually approaching that position.

The sub-genus Najadicola differs in the following respects. The fore legs are not thickened, and all are short, with few short spines and simple claws. The genital area is not at the end of the body but immediately behind the last epimera and as Koenike's figures show, bears a certain resemblance to

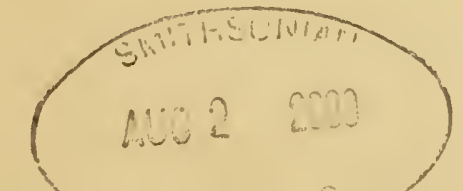


that of Cochleophomus. It is, however, much broadened transversely, and each genital plate is triangular in outline. There are no spines about the genital opening of the female and the lack of these is correllated with the method of oviposition, $A$. $(N$.$) ingens Koenike depositing its eggs in masses between the$ gills and not in them.

Of the genus Atax as thus defined there have been heretofore described 22 valid species, distributed geographically as follows:

From Europe, 8: A. aculeatus Koenike(Germany), A. Bonzi Claparède (Germany, Sweden, Switzerland, France, Russia) A. cressipres (Miiller) (Finland, Russia, Switzerland, Denmark, Germany, Italy, France), A. figural is Koch (Germany), $A$. intermedius Koenike (Belgium, Germany, Russia), A. limosus (Koch) Berlese (Italy, Germany), A. tricuspis Koenike (Germany) A. ypsilophomes (Bonz) (Sweden, Germany, Switzerland, France).

From Asia, 3: A. crussipes (Miiller) is recorded from Palestine, and _. S. Schmeckeri Koenike was described from Shanghai, China, while Daday has recently published one from Ceylon, A. singalensis, while his $A$. nodosus belongs to Cochleophoms.

From Africa, 1: A. lynceus Koenike from East Africa.

From Brazil, 6: A. Ampullaric Koenike, A. fissipes Koenike, A. Sheringi Koenike, A. perforatus Koenike, A. procurvipes Koenike, A. rugones Koenike, all from the province of Rio Grande do Sul.

From Guatemala, 3: A. alticola Stoll, A. dentipalpis Stoll and $A$. septem-maculatus Stoll.

A. alzutei Alf. Dugès, described from Mexico, is a species of Curvipes.

From North America, A. ypsiloplores (Bonz) has several times been recorded and Koenike adds to it from Canada $A$. forsulatus Koenike and $A .\left(\Lambda_{\text {. }}\right.$ ) ingens (Koenike).

Our own literature is not entirely wanting in references to this genus, but the work done by Americans has for the most part been practically worthless, while efforts made to secure the original specimens have resulted in failure, as would be ex- 
pected from the number of years that have elapsed, the nature of the specimens, and the crudity of methods of preservation in vogue at the time they were described.

Thos. Say, in 1821, described Iyydrachna triangularis from Unio cariosus Say; in so doing he may have re-described Atax ypsilophorus (Bonz) as other authors have inferred, although from his description it is impossible to say which species he had under observation. In 1836, James D. Dana and James Whelpley, in Silliman's Journal, described two forms, IIydrachna formosa from "Anodonta cataracta" (A. fluviatilis Dillw.) and "Unio purpurata" (an incorrect identification as U. purpuratus Lam. is Southern in its habitat); and Iydrachna pyriformis from Margaritana undulata Say. The former is another synonym of $A$. ypsilophorus (Bonz), the latter a distinct species, but the characters given are not sufficient for exact determination. Its form and the character of the claws which are described as simple, seem to show that it is a female of either $A$. abnormipes mihi or $A$. indistinctus mihi, but of which it is impossible to tell. In 1842, S. S. Haldeman described under the "Genus? Unionicola" nine species: oviformis, lactea, personata, humerosa, symmetrica, proxima, lugubris, unicolor and reticulata-with very short descriptions, based mostly on color. Two of the nine are identical with $A$. ypsilophorus (Bonz), while the other seven are probably the same, as Koenike (95b) suggests. Joseph Leidy, in 1883, noted the presence of the same European form in Anodonta Aluviatilis Dillw. from New Jersey, and mentions the occurrence in Unio complanatus Sol. of a second species, "probably", he says, "A. Bonzi", also a previously described European form. In 1891, F. Koenike of Bremen, Germany, published a preliminary account (91c) of some material received from Dr. Tyrrell in Ottawa, Canada, confirming Leidy's observation as to the occurrence of $A$. ypsitophomes (Bonz) in North America, but, and it seems rightly, throwing doubt on his identification of A. Bonzi Claparède. In 1895 , a fuller paper (95b) on the same material by the same author appeared and in it he enumerated the species previously 
mentioned-A. ypsilophorus (Bonz), A. fossulatus Koenike and $A .(N$.)ingens (Koenike).

The collection of material upon which the present paper is based was begun in 1893 and has been carried on, as opportunity offered, ever since. During the five years the following collections of Unionidæ have been made and examined for mites:

August, 1893, at Lake Saint Clair, Mich., 257 specimens of Unio gracilis Barnes, U. luteohus Lanı., U. nasutus Say, U. alatus Say, $U$. ventricosus Barnes, U. gibbosus Barnes, $U$. rectus Lam., $U$. coccineus Hild., $U$. undulatus Barnes, $U$. occidens Lea, Margaritana rugosa Barnes, M. deltoides Lea and Anodonta oveata Lea.

October, 1893, at Lansing, Mich., from the Cedar River, about a score of mussels, belonging to several species, the record of which is, unfortunately, lost.

July and August, 1894, at Charlevoix, Mich., from " 26 " Lake, Twin Lakes and Susan Lake, small inland lakes in the vicinity, and from Round Lake, opening into Lake Michigan, and also from Intermediate Lake at Ellswortll, Mich., 116 specimens of U.luteolus, M. rugosu, A. subcylindracea Lea, $A$. footiuma Lea, $A$. edentula Say and $A$. fragilis Lam.

August, 1894, in two small lakes on Beaver Island, L. Michigan, 85 specimens of $U$. luteolus, A. footiana, A. fragil is and $A$. marryatana Lea.

July and Angust, 1895, from Grand River and smaller streams, and from Reed's Lake, near Grand Rapids, Mich., 273 specimens of $U$. coccineus, $U$. gitbosus, $U$. ventricosus, $U$. occidens, $U$. rectus, $U$. undulatus, $U$. plicatus Lea, $U$. alatus, U. ligamentinus Lam, U. spatulatus Lea, U. Novieboraci Lea, U. mbiginosus Lea, U. pustulosus Lea, U. Schoolcraftii Lea, $U$. verrucosus Barnes, $U$. luteolus, $M$. mugosa, $M$. marginata Say, $A$. ovata, A. edentula, $A$. footiana, $A$. subcylindracea, A. fragilis, $A$. imbecilis Say.

July, 1897, from Rogue River, Kent County, Mich., and from Reed's Lake, Grand Rapids, Mich., 21 specimens of $U$. 
occidens, U. spatulatus, $M$. deltoides, $M$. marginata, $A$. footiana, and $A$. subcylindracea.

August, 1895, at Long Lake, Kalamazoo, Mich., 13 specimens of $U$. luteolus, $U$. ventricosus and $A$. footiana.

August, 1895, at Black Lake, Holland, Mich., 10 specimens of $U$. luteolus and $U$. ventricosus.

July and August, 1898, from various localities along Grand River, near Grand Rapids, Mich., from the mill-pond at Mill Creek, near Grand Rapids, from Reed's Lake, and from Plaster Creek, in the same vicinity, 534 specimens of the species previously enumerated from the same localities, with the addition of $U$. pressus Lea.

August, 1898, at White Lake, Muskegon county, Mich., 86 specimens of $U$.luteolus, A. subgibbosa Anth., A. subcylindracea, A. footiana and M. complanata Barnes.

August, 1897, at Lake Winnebago, Oshkosh, Wis., 21 specimens of $U$. gracilis, $U$. luteolus and $A$. grandis Lea.

October, 1894, from Blue River, Crete, Neb., 2 Unio luteolus.

Octcber, 1894, from pools near Lincoln, Neb., 19 specimens of $U$. parvus Barnes, U. subrostratus Say, U. jamesianus Lea and $A$. grandis.

October, 1894, from Platte River, South Bend, Neb., 1 A. grandis.

October, 1894, from Weeping Water Creek, Weeping Water, Neb., about 50 specimens of $U$. subrostratus, $U$. rubiginosus, $U$. undulatus, U. jamesianus and $M$. complanata.

September, 1895, from the same locality, 24 of the same species.

September, 1895, from near Lincoln, Neb., 20 U. lachrymosus Lea, $A$. plana Lea, and $A$. decora Lea.

September, 1897, from the Blue River, at Milford, Neb., 42 specimens of $U$. lachrymosus $U$. ventricosus, $U$. Schoolcraftii, $U$. anodontoides Lea, $M$. complanata, $A$. plana and A. grandis.

Thus, personally, the author has examined nearly 1,600 
specimens of Unionidæ, representing a large number of localities and 39 species.

Through the kindness of Mr. R. H. Johnson of Harvard University the material obtained from the following mussels has been received for examination:

Angust, 1897, from Lake Chautauqua, New York, 150 specimens of $U$. phaseolus Hild., U. gibbosus, U. luteolus, $A$. edentula and $A$. plane.

August, 1897, from Cayuga Creek, Cheektowaga, Erie county, N. Y., a number of $U$. occidens.

To Prof. H. M. Kelly of Cornell College, Mt. Vernon, Iowa, the author is indebted for the data and mites obtained from the examination of the following large number of mussels, collected during the years 1896 and 1897:

From the Illinois River and bayous and lakes near Havana, Ills., 731 specinens of $U$. alatus, $U$. asperrimus Lea, $U$. anpdontoides, $U$. comutus Barnes, $U$. donucifomnis Lea, U. ehenus Lea, $U$. cllipsis Lea, U. graniferus Lea, $U$. elegans Lea, $U$. gibbosus, U. Higginsii Lea, U. gracilis, U. laevissimus Lea, $U$. ligrmentinus, $U$. luteolus, $U$. lachrymosus, $U$. metanever, Raf., U. multiplicatus Lea, U. parvus, U. pustulatus Lea, U. pustulusuri, U. mbiginosis, U. plicatus, U. securis Lea, $U$. tenuissimus Lea, U. trigonus Lea, U. rectus, U. tuberculatus Raf., U. ventricrsise, H. rugosa, M. marginata, M. confragosa Say, M. complanata, A. imbecilis, A. plana, A. suborbiculata Say, $A$. edentula and $A$. corpulenta Coop.

From the Spoon River at Bernadotte and Duncan's Mills, Ills., $19+$ specimens including the greater number of the above species.

From Abbey Creek and Cedar River, Mt. Vernon, Iowa, 486 specimens, including also the majority of the same species.

From the Susquehanna River at Lewisburgh and Sunbury, Pa., and the Schuylkill River and French Creek near Phoenixville, Pa., 202 specimens of $A$. edentula, M. undulata, $M$. marginata, $U$. complanatus Sol., $U$. heterodon Lea, $U$. nasutus, U. ochraceus Say and U. tappanianus Lea. 
Mr. M. Ricker of Burlington, Iowa, has kindly sent a small collection of mites obtained at Havana, Ills., from the same species of Unionidæ enumerated in the above list.

The present paper embodies, thus, the results of the examination of nearly 3,500 mussels, representing 60 species, and from them have been collected and preserved about 7,000 mites, belonging to 13 species, of which 7 are new and 3 more are reported from America for the first time. Search has been made for mites in Pisidium and Sphcerium but with success in only one instance, when two individuals of $A$. crassipes (Muiller) were found in a species of Sphorium, and in Campeloma, Physa, Limnea and Goniobasis, but so far without results.

In this enumeration and throughout the paper the author has avoided any attempt to pass judgment upon the validity of the different species of mussels referred to, and has included many names which he himself believes to be synonyms, as for instance, Unio occidens Lea and $U$. ventricosus Barnes, in order that there should be in this way no omissions of species which others might believe distinct from those given. All the names given have been more or less generally recognized and the reader is requested to make his own synonymical corrections in accordance with his opinions.

The specimens of mites obtained were studied alive, preserved in various fluids, and mounted upon slides to allow of thorough microscopical examination. Without, at first, sufficient knowledge of the weight of specific characters, too much dependence was placed upon color, which, it is found, has almost no value in identification, though the brilliancy of coloration is one of the principal features which make the group such an exceedingly attractive one for study. Later certain structural characters were fixed upon, which, by their similarity in allied species, led to confusion; and differences, too, which were at first assumed to be sexual, were found later, when the true sexual characters were discovered, to be specific. Finally, especially at first, the mites coilected from a single species of mussel and bearing a close resemblance were assumed to be identical and only found to include more than one species after 
the accumulation of individuals in vials prevented the correction of the recorded notes. These, together with a lack of that familiarity with the Unionidæ necessary to make sure identifications at the time of examination and consequent occasional confusion in the recording of observations, impair the value of early notes and collections. The facts are mentioned that others may be warned thereby, and in order that certain allusions in the descriptions which follow may be understood. It may be said here, that in the case of more recent collections, care has been taken to keep the mites from each mussel separate until careful examination under the microscope, of the structure of palpi, legs, genital area, etc., has allowed of exact identification of each individual mite.

As to preserving fluids, alcohol, corrosive sublimate, picrosulphuric, Flemming's and other solutions were at first used. Of these corrosive sublimate gave the best results, but all have been rejected as making the specimens too brittle and leading to serious breakage of appendages. Formol does not preserve the color effectually and is partly open to the same objections. Yet a certain proportion of the specimens collected have always been preserved in either it or the media previously mentioned, to allow of their being studied in various ways. A solution recommended by Koenike (91c) and consisting of

Glycerine..............2 parts by vol.,

Distilled water............. 3 parts by vol.,

Glacial acetic acid..........2 parts by vol.,

Absolute alcohol............. part by vol.,

has been found to preserve the specimens in the best condition for future study, since although it cannot be recommended as a preservative either of form or color, it keeps the body soft and the appendages pliable, and thus they lend themselves the nore readily to methods of preparation used in making slide mounts.

A solution consisting of

Glycerine............ 10 parts by weight,

Citric acid, concentrated solution, 3 parts by weight,

Distilled water........... 10 parts by weight, to which is added, when the mites have regained their plump 
form after being tirst shrivelled by being put into the mixture, Absolute alcohol.......1-10 of the total volume, is recommended by Koenike (96) as an improvement over his previous formula, and has been of late used in place of it, without sufficient time having elapsed to judge of its merits.

In the preparation of slide mounts, specimens are removed from the preservative, thoroughly washed in distilled water, treated with a dilute potassium hydrate solution, a rent made in the skin and through it the contents of the body pressed out, again thoroughly washed, passed through the grades of alcohol and clearing mixture and finally mounted in balsam. By this means a perfectly transparent mount is obtained and all the hard parts are readily studied. There is more or less distortion, but comparison with specimens preserved in other media assists in obtaining a correct view of the relations of the hard parts, which are themselves in perfect condition. The mouthparts are removed from the body, separated by dissection and also mounted for detailed examination.

The study of the material collected has resulted, as before stated, in the detection of 13 species, of which 7 are new and have been briefly described in a preliminary paper published in the Zoological Bulletin for June, 1898. The list is as follows:

1. Atax crassipes (Miiiler).

2. Atax aculeatus Koenike.

3. Atax pectinatus mihi.

4. Atax intermedius Koenike.

5. Atax abrormipes mihi.

6. Atax indistinctus mihi.

7. Atax serratus mihi.

8. Atax fossulatus Koenike.

9. Atax strictr mihi.

10. Atax arcuata mihi.

11. Atax ypsilophorus (Bonz).

12. Atax tumidus mihi.

13. Atax (Najadicola) ingens (Koenike).

In the arrangement of these species in the order given, an attempt is made to preserve the sequence in which the Eu- 
ropean forms have usually been arranged and with the end in view of bringing allied species together. First the two freeliving forms, together with a third, parasitic in habit, but resembling the other two very closely in form and structure, fall naturally into what may be called the crassipes group, $A$. crassipes, $A$. aculeatus and $A$. pectinatus. Then the forms in which the hind leg of the male is modified and in which, in the same sex, the body is more or less strongly emarginate posteriorly and which in both sexes have the distal segment of the palpus broad and tipped with two prominent curved claws, forn a second group, the intermedius group, including $A$. intermedius, A. abnormipes, $A$. indistinctus and $A$. serratus. A third group includes $A$. fossulatus and $A$. stricta, with 5 acetabula on each side, in the female set into the surface of the body, in the male on a genital plate; while $A$. arcuat,$A$. ypsiloplomus and $A$. tumidus form a not very homogeneous group, the members of which are related in form of body, character of genital area, etc., and which in structure and position of the genital area show a gradual transition towards $A$. $(N$.) ingens, which itself is related on the other hand to Cochleophomes.

In the descriptions which follow, the terms used need no explanation except perhaps with reference to the palpi and legs; the former are supposed to be extended parallel to the long axis of the body, whence the terms inner and outer, dorsal, extensor or upper, and ventral, flexor or lower, as applied to the corresponding surfaces. The legs are supposed to be at right angles to the body and the terms anterior and posterior become applicable. The names applied to various parts are such as have hitherto been applied or are literally translated from the corresponding terms in use by European writers on the subject.

Measurements have been taken with an ocular micrometer. The length of the body is that of the body proper, and the projecting mouth-parts are not included; the length of a segment is the length of a straight line connecting the middle points of its two ends; and the total length of an appendage is the sum of such lengths of the segments which compose it. In 
all measurements of legs which follow the claw is not included in the total. For the sake of brevity the $\operatorname{legs}$ and the epimera corresponding are frequently referred to by Roman numerals and the segments of the legs and palpi are numbered from the base ontward, using Arabic numerals; thus "III 3" refers to the third segment of the third pair of legs, and "Palpus 5" to the distal segment of the palpus.

\section{DESCRIPTION OF SPECIES.}

\section{Atax Crassipes (Müller).}

Hydrachna crassipes Müller, 1776; 189, no. 2254: id., 1781; XLI, Pl. IV, f. $1,2$.

Trombidium crassipes Fabricius, 1792; II, 400.

I, f. 1.

Atax crassipes Fabricius, 05; 366: Koch, 35; 7, 21: id., 37; III, 8, Pl.

Atax elegans Koch, 35; 7, 12.

Atax truncatus Koch, 35; 7, 22.

Atax albidus Koch, 35; 7, 23.

Atax confluens Koch, 35; 7, 24 (nymph).

Atax truncatellus Koch, 35; 37, 17 (nymph).

Hydrachna crassipes Walckenaer and Gervais, 44; III, 197.

Atax crassipes Bruzelius, 54; Pl. I, f. 1-4: Claparède, 68; 471: Kramer, 75; 293: Lebert, 79; 368, Pl. XI, f. $10,10 \mathrm{a}$; Neuman, 80; 21, Pl. I, f. 1: Koenike, 81a; 627: id., 81b; 356: Haller, 81a; 76: Berlese, 82; fasc. IV, no. 7: Krendowsky, 85; 55: Barrois and Moniez, 87; 5: Piersig, 94b; 214: Koenike, 95a; 139: id., 96a; 232: Piersig, 96; 40: id., 97; Lief. I, 52, Pl. III, f. 5, a-h.

Atax crassipes is noteworthy among the species of this genus, for the great length of its legs, which cover a greater area than those of any other species, though its body is smaller than many others. The body of the male varies in length from 0.5 to $0.7 \mathrm{~mm}$., while the female is from 0.7 to $0.9 \mathrm{~mm}$. and even 1.1 or $1.2 \mathrm{~mm}$. long. Its form is broadly oval, with the larger encl of the oval anteriad and evenly rounded, the smaller end posteriad and truncate, projecting nipple-like papillae at either side giving this end the appearance of having been cut squarely off. The greatest breadth is about opposite the third epimeron. The nipple-like papillae exhibit varying degrees of prominence and Piersig describes a muscle which serves as a retractor and by which they may be made to completely disappear.

The double eyes are very large, blackish in color, close to the margin and moderately distant from each other, in a specimen $0.618 \mathrm{~mm}$. long being $0.184 \mathrm{~mm}$. apart. The anterior portion of each eye is larger and nearly twice as large as the posterior. 
The mandibles are nearly typical in form, though a little longer than the average for the genus, the maximum width being equal to about onethird the length, which in the specimen just referred to is $0.148 \mathrm{~mm}$. The greatest breadth is near the posterior end; the dorsal margin is slightly concave, the posterior dorsal angle rounded, the posterior ventral angle produced, forming a point of muscle attachment, and the ventral margin nearly straight; a shallow mandibular groove is present. The distal segment includes about one-third the total length, and most of this is made up by the slightly curved and rather slender claw, which is indistinctly hooked at the tip and marked on the inner side toward the base by slightly curved oblique striae, which are vertical to the line of insertion of the claw.

Palpi, long and slender, segment 1 about half as thick as it is long: 2 the thickest of all and nearly as thick as long; 3 about two-thirds as thick as 2 , and a little over half as long; 4 , longest of all, but only about half as thick as 2; 5 slender, curved, at the base nearly as thick as 4, but at once strongly contracted and throughout most of its length with the dorsal and ventral surfaces nearly parallel. From above or below the palpi appear even more slender than from the side, the extreme width of 2 at about the middle being only three-fourths of its thickness and the palpus tapering gradually and evenly from this point to the tip which is blunt and bears very small claws; 2 has two small spines on the outer side close together and near the dorsal margin, and one on the inner side near the middle, with a second very small one close to the base; 3 has a very long stout spine in the middle of the outer side and one smaller but still long and stout on the dorsal side near the distal margin. On 4 are the three papillae characteristic of the genus, the two being but a little beyond the middle of the segment, the third at the distal margin, and all three being exceptionally long and slender. The outer of the two is the longest and its length equals the thickness of the segment, the third at the distal end is about two-thirds as long as the outer, and the inner of the two only about one-third as long. The two bear each a small hair, the third a broad chitinous cap. There is, finally, a long slender hair on the outer side of this segment near the base.

The maxillary shield, as far as its main portion is concerned, is broad, short and evenly rounded posteriorly, with a rather prominent rostrum anteriorly; the ancoral process is nearly as long as is the main portion, is broad at its base, its lateral margins forming with the anterior part of the margin of the former a nearly straight line; and tapers to a narrow tip, which is produced to either side forming recurved hooks.

The epimera are rather large, especially the posterior group, and the spaces between the groups are narrow in the male, wider in the female. The posterior margin of the anterior group is strongly convex while at one- third the distance from the inner to the outer end and opposite the suture between I and II, the two give rise to a long curved process which runs back to a considerable distance beneath III. The separation between III and IV is represented by a line at about two-fifths the distance from the anterior margin and which curves from the outer side obliquely 
inward and forward about half way acrosss the plate formed by the two. This plate is nearly rectangular, somewhat longer than broad, with the anterior margin slightly concave, and the inner slightly convex. On the thickened border at the inner posterior angle are two hairs.

The legs, as before stated, are very long, all considerably exceeding the body in length. Measurement of several specimens show a variation in the relative length of legs and body and in the relative lengths of the legs themselves, but this variation seems to possess neither locality, sexual nor specific significance. In a single specimen from Lake St. Clair the third pair of legs exceeds in length the first, but in all other cases III is the shortest, nearly equalling I, and II and IV are considerably longer, with IV a little longer than II and more than twice the length of the body. In all eases the order of length of the individual segments in II and III is as follows, beginning with the longest $-5,4,6,3,2,1$; in I, 5 and 6 are of about equal length, and both shortened, being shorter than 3 ; in IV, 6 is lengthened and surpasses 4. In the case of I, 2 possesses a ventral papilla, projecting chimney-like to a distance equal to two-thirds of the thickness of the segment, deeply excavated and open at one side and receiviug into this excavation a long movable spine, while there is also a short movable spine at the outer margin of the posterior side; 3 has two movable spines on either side ventrally; 4, four in two ranks on the proximal half of the ventral surface; 5 a row of four towards the base and one at the tip on the ventral side, of the former the first and third being the longer. All of these spines are widest at a little distance from their insertion tapering gradually to a blunt tip, and more rapidly to their point of insertion. The fifth segment has the dorsal surface produced forming a scoop-like shield over the insertion of the next segment. 1,2 and 3 are very stout, 4 tapers considerably towards the tip, 5 and 6 being noticably slenderer and 6 somewhat curved. II, III and IV are slenderer at the base than I, and taper gradually from base to tip; they possess a moderate number of long, slender, straight spines which form groups on the tips of segments II 5 , III 4, III 5, IV 4 and IV 5 , while on IV 3, numerous spines are scattered along the ventral surface. On I the claws are rather stout, mucl curved and bifid, the ventral of the two tips being the stouter; on the other legs, however, the claws are longer, much more slender and the two tips are long, slender and sharply pointed, while the dorsal of the two is not so long as the other and thus forms an accessory claw arising at a distance from the tip equal to one-fourth the length of the claw.

The genital cleft in the female is flanked by four chitinous plates, of which the two anterior are irregularly rectangular with rounded angles and the two posterior roughly triangular with the angles also rounded. Each bears three acetabula and numerous slender spines, and six longer and stouter spines are borne-two each by the anterior plates and one each by the posterior-on their contiguous angles which are somewhat produced and directed outward. The male also possesses twelve acetabula but they are borne on two lunate plates, one on either side, and are distributed on each plate in two groups of three each. 
On either side of the genital area is a large nipple-like papilla, which varies in prominence, and which, according to Piersig, can be retracted by a muscle running to it from the last epimeron. Koenike ( $81 \mathrm{~b})$ believes these papillae to contain highly developed epidermal glands.

MEASUREMENTS,

\begin{tabular}{|c|c|c|c|c|}
\hline & $\begin{array}{l}\text { Male. juv } \\
\text { Grand Rapids, Mich. }\end{array}$ & $\begin{array}{l}\text { Male } \\
\text { Beaver I'ds. }\end{array}$ & $\begin{array}{c}\text { Female } \\
\text { Beaver I'ds. }\end{array}$ & $\begin{array}{c}\text { Female } \\
\text { Lake St. Clair. }\end{array}$ \\
\hline Length of body, & $0.367 \mathrm{~mm}$. & $0.701 \mathrm{~mm}$. & $0.835 \mathrm{~mm}$. & . $\quad 1.002 \mathrm{~mm}$. \\
\hline ength of $\operatorname{leg} \mathrm{I}$, & $0.683 \mathrm{~mm}$. & $1.234 \mathrm{~mm}$. & $1.357 \mathrm{~mm}$. & $1.596 \mathrm{~mm}$. \\
\hline ength of leg II, & $0.842 \mathrm{~mm}$. & $1.525 \mathrm{~mm}$. & $1.657 \mathrm{~mm}$. & $2.081 \mathrm{~mm}$. \\
\hline agth of leg III, & $0.632 \mathrm{~mm}$. & $1.193 \mathrm{~mm}$. & $1.285 \mathrm{~mm}$. & $1.632 \mathrm{~mm}$. \\
\hline $\begin{array}{l}\text { ength of leg IV, } \\
\text { ength of palpus, }\end{array}$ & $0.872 \mathrm{~mm}$. & $\begin{array}{l}1.596 \mathrm{~mm} . \\
0.357 \mathrm{~mm} .\end{array}$ & $\begin{array}{l}1.708 \mathrm{~mm} . \\
0.393 \mathrm{~mm} .\end{array}$ & $\begin{array}{l}2.112 \mathrm{~mm} \text {. } \\
0.403 \mathrm{~mm} \text {. }\end{array}$ \\
\hline
\end{tabular}

Atax crassipes was first met with Sept. 1st, 1893, in material dredged over a bed of Chara in Anchor Bay, Lake St. Clair, at a depth of about 3 meters. Specimens were again secured near the same locality on the $3 \mathrm{~d}$, and in that vicinity again on the 12 th, at a depth of 5 meters. It was collected in the southwestern part of the lake on the 8th and 10th at depths of 5 and 6 meters respectively, and off Point Pelee Island, Lake Erie, on the 17 th, at a depth of 5 meters. Altogether 29 specimens were secured. It appeared to be of general distribution over the Chara which carpets the bottom of Lake St. Clair, a lake which though of an area of 410 sq. miles is over its deeper portion only about 6 meters in depth.

During the summer of 1894 , specimens, parasitic as well as free, were collected at several points in Northern Michigan. They were found in Round Lake at Charlevoix, July 9th to 13th, at depths of 16 to 18 ineters, in limited numbers; July 31st a specimen was secured in bottom collections from Lake Michigan off Fisherman's Island, a few miles west of Charlevoix, at a depth of about 10 ineters, and on August 18th the species was obtained in bottom tows in Lake Michigan between Beaver and High Islands at depths of 10 and $23 \frac{1}{2}$ meters. Aug. 6th the species was found at Twin Lakes and " 26 " Lake, small inland lakes near Charlevoix, on Aug. 21st at Susan Lake, another similar lake in the vicinity, and in material collected on the same day at Intermediate Lake, also not far distant. Sept. 5th Dr. R. H. Ward collected specimens 
at Dodge Creek, Emmet County, so that the species may be accounted as generally distributed throughout the smaller inland lakes of Northern Michigan, and also in Lake Michigan and the smaller lakes in connection with it, though present nowhere in large numbers. Mr. Bryant Walker, a conchologist and a member of the same party as the writer, turned over to him two speciniens of an Atax from Sphorium simile Say, collected in "626" Lake Aug. 6th, and on the 17th of Angust specimens of adults and nymphs were secured in considerable numbers from Anodonte footiana and Anodonta fragilis taken in a lake at the north end of Beaver Island, Lake Michigan. All of these have been carefully studied from mounts and the author has been unable to detect any characters by which any of them may be distinguished from Atax crassipes.

Specimens were collected at Grand Rapids, Mich., during the months of July and August, 1896 and 1897, in Reed's and Fisk's Lakes, and in a third very small lake near the city. The former are lakes of moderate size and with a depth of 20 meters or more, but the latter is liardly more than a pool in the midst of a cranberry bog, 50 meters across, and with scarcely more than a meter of clear water above the loose, half-floating, semi-decayed vegetable mould which forms the bottom of such lakes. All are spring-fed. Two specimens, apparently of this species, were collected in two examples of Anodonta fragilis from Reed's Lake, July 23, 1898.

From Mr. J. B. Shearer have been received specimens collected in Quannecussec River, an arm of Saginaw Bay, Lake Huron, in the Kawkawlin River, an affluent of the same bay, and at Les Chenaux Islands, in northern Lake Huron, near Mackinaw, all obtained during August, 1895.

In Wisconsin, the author has collected this form in Lake Winnebago, at Oshkosh, Sept. 2, 1897, while he has received it from two localities in Nebraska,_-in a collection made by Dr. H. B. Ward at a lake at South Bend, Sept. 2, 189T, and from material obtained by Mr. O. D. Noble in a "stagnant spring-fed pool" at Linwood, Sept. 1898. 


\section{ATAX ACULEATUS KOENIKE.}

Atax crassipes juv. Claparède, $68 ; 471, \mathrm{Pl}$, XXXIII, f. 1-3.

Atax aculeatus Koenike, 90 ; 138: id., 95d; 386, f. 13: Piersig, 96; 40, footnote: id., 97; Lief. I, 59, Pl. I, f. 3.

A. aculeatus is very closely related to $A$. crassipes and can best be described by comparing it directly with that species. It is similar in form, but so far as the author's observation goes never reaches as great size, the males attaining a length of from 0.5 to $0.6 \mathrm{~mm}$., the females 0.65 to $0.75 \mathrm{~mm}$.

The mandibles are similar in form as is also the maxillary shield. The eyes are very large, black and rather close together.

The palpi share in the resemblance, though they are apparently a trifle more slender and are proportionately longer.

The epimera occupy even more of the under surface of the body and in the male the four groups are almost in contact.

The legs are very long as in $A$. crassipes and the proportions similar, though those of A.aculeatus seem slightly stouter than in the allied species. The sixth segment is, however, somewhat longer in III and exceeds 4 . In $\mathrm{I}, 4$ is the longest and 5 and 6 approximately equal to each other, while both exceed $3 ; 6$ is also not quite so slender as is the case in A. crassipes and is less curved and a little dilated at the tip. The ar'rangement and length of the spines on the legs are practically the same in the two species. The claws are similar.

The genital ficld in the present form is characteristic and markedly different from that of $A$. crassipes. There are but ten acetabula instead of twelve, in the male situated on two kidney shaped plates which flank the genital cleft. On each side two anterior acetabula are placed one directly behind the other, and are separated by an interval from the three posterior, of which the two anterior lie side by side. The cleft is longer than in $A$. crassipes and in the case of all specimens on slides gapes widely. In the female the single lateral plate is divided into two, the anterior of which is pouch-shaped with the neck of the pouch directed anteriad, while the posterior is similar in outline but inverted. The former has two acetabula, the latter three. The ovipositor is prominent and of characteristic form. From each side of the genital opening projects a plate which anteriorly and-since the genital area is on the posterior surface of the body-also, ventrally, is produced and turned outward forming a conical process, at the top of which is articulated a short, thick, sharply-pointed spine. At the base of this, internally, is a small sharply-pointed process, and from the posterior-and dorsal-margin projects a longer, tapering and sharply pointed process, both of these processes being not set into sockets, but apparently continuous with the rest of the plate. By the apposition of these two plates, they are able, probably, to serve together as an ovipositor. 
At either side of the genital area is a conical papilla, similar to that found in $A$. crassipes but still more prominent.

MEASUREMENTS.

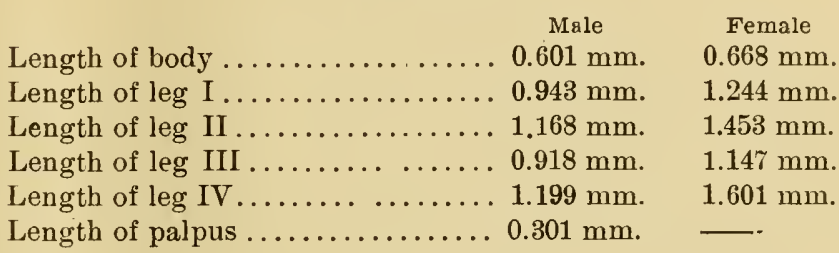

In the examination of mussels from Grand River, at Grand Island near Grand Rapids, Mich., July 9, 1896, nymphs of different species of mites and also dead mites were found in the mucous about the exhalent aperature of many individuals. Little notice was taken of these until in Unio ligamentinus, $U$. alatus and Anodonta edentula, a few adults were found; these were, however, on cursory examination, supposed to be Atax crassipes. A more thorough examination later showed them not to be that species and to belong probably to Atax aculeatus, a determination which has since been verified. On the 5th of July, 1897, six specimens were found along the edge of the mantle of Unio spatulatus from the Rogue River, Kent County, Mich. During the past summer especial care was taken to examine all mites and nymphs occurring in the situations referred to. It was found that most of them were nymphs and of these the majority were $A$. abnormipes, a smaller number were $A$. aculeatus, a still smaller, $A$. intermedius, and now and then one of $A$. serratus or $A$. fossulatus, all of these species being reared from such nymphs. Of all, only $A$. aculeatus was represented by adults, while this species in its adult form seemed to occur nowhere but along the margin of the mantle and about the exhalent and inhalent aperatures, situations which its slender form and superior activity enable it to maintain. The mussels from which it was obtained were $U$. rectus, $U$. gibbosus, U. undulatus, U. ligamentinus, U. occidens, U. ventricosus, U. spatulatus, U. Novi-eboraci, U. coccineus, all from different localities along Grand River, north of the city of Grand Rapids, Mich.; Unio pressus and Anodonta plana, from Plumb's Creek, 


\section{near that city; and Unio luteolus, from White Lake, Muskegon County, Mich. The dates were from July 27 th to August 30 th.}

\section{ATAX PECTINATUS WOLCOTT.}

Atax pectinatus Wolcott, $98 ; 280$.

A species, in the character of the genital arca allied to $A$. crassipes and $A$. figuralis Koch, but with the legs relatively shorter than either and with the palpi very thick, considerably thicker than the basal segment of the first pair of legs. The claw of this pair of legs is broad, flat and deeply pectinate, which character suggests the specific name.

It is of medium size as compared with the other species of the genus, the males measuring 0.7 to $0.8 \mathrm{~mm}$, the females 0.8 to $1.0 \mathrm{~mm}$. in length respectively. 'l'he body is broadly elliptical with the antero-posterior diameter but slightly greater than the transverse, which is greatest at a point about midway between the anterior and posterior extremities. The posterior margin is smoothly rounded and the surface is nuiformly smooth and without chitinous thickenings of any kind. The males are somewhat slenderer than the females.

Eyes moderate in size, with the anterior of the two lenses the larger.

Maxillary shield relatively short and broad, with a prominent rostrum formed by the apposed anterior mesial angles of each of the two maxillary plates which are completely fused anteriorly. The posterior lateral angles are quite evident though ronnded while the ancoral process produced by the apposition of the two produced posterior mesial angles is, as compared with other species, very weak.

Mandibles with a long, narrow proximal segment which is slightly broader posteriorly where it is directed somewhat ventrad and tapers to a bluntly rounded point, in front of which is a shallow mandibular groove. Its form is irregular owing to the undulating marginal outline. Distal segment large, with a broad basal portion and a sickle-sliaped claw which is moderately curved except toward the tip, where the curvature is more pronounced and where it tapers somewhat more rapidly than before to a sharp point. The proximal half of this claw is marked by fine, wary, oblique lines. Extreme breadth equal to about one-fourth its total length.

Palpi large and heavy, those of the female somewhat more than twofifths the length of the body. Those of the male are very little smaller than those of the female in absolute measurement and are therefore larger in proportion to the size of the body. Basal segmentshort and broad. Segment 2 is the largest and much the thickest, equaling nearly one-half the total length and with a thickness in proportion to the length as 5:9. The flexor side is nearly straight, with a very slight concavity, the extensor side very conver and evenly so, making it much longer than the other and causing the planes of the two ends to be very oblique to one another. On the inner side of segment 2 are two flattened spines rather near together, at a distance from the basal margin of about one-third the length of the segment, and a third one-half the distance from these to the distal end, all three being nearer the extensor than the flexor side of the palpus. On 
the outer side are two toward the extensor margin, the distance between them somewhat less than one-third the length of the segment. Segment 3 is much shorter than 2 and not so broad, yet broader than long. Its flexor side is half the length of the extensor, each of them with a slight convexity, and there is a small straight spine on the outer side, while 4 is longer and narrower, concave on its flexor surface, moderately convex on the opposite side. The former bears distally a pair of not very prominent papillae and a short spur at the distal margin. Segment 5 tapers at first rapidly, then more gradually to a blunt, rounded tip, produced slightly toward the flexor side and bearing at the distal end four short claw-like projections arranged in quadrille, while immediately proximad of them arotwo very short spines.

Epimera covering about the same proportion of the ventral surface as do those of $A$. figuralis, but II and III and those of opposite sides are separated only by very narrow spaces, narrower in the male than in the female. Outline of the fused I and II approximately triangular, the apex of the triangles of the two sides nearly meeting in the median line. The anterior margin of this triangular plate is slightly excavated and the posterior forms a double curve, being convex for the inner two-thirds of its length and beyond that concave. I is long and narrow, broadly expanded at its outer end, where it is moderately excavated to receive the first pair of legs, while II is broadly triangular with the anterior external angle truncate. The plate formed by the fused III and IV has a slightly concave anterior margin, a nearly straight inner margin, and a posterior margin slightly convex, all the angles being rounded. The epimera of the opposite sides approach each other most closely in front. A transverse suture two-fifths of the distance from the anterior to the posterior margin indicates the line of junction of the two epimera.

The legs are shorter than in the related species and relatively longer in the male than in the female. In the former I is slightly longer than the body, II and III about equal and each a little less than one-third longer, IV about two-thirds longer. I of the female is almost four-fifths of the body length, II and III somewhat exceed it and IV is greater by a little more than one-third. Of the individual segments 1 is the shortest and the others gradually increase in length to 5, but 6 is again shorter. I is slightly heavier than the rest, though as a whole the legs are decidedly weak and the distal segments especially slender. There are no movable spines on I set into projecting sockets as in $A$. crassipes and A. figuralis, their number is somewhat less, and individually they are shorter and more slender and taper to a sharp point. The claws are characteristic. Those on I are expanded dorso-ventrally and flattened laterally, forming a broad plate of which the dorsal margin is strongly arched, the flexor margin deeply pectinate, the pectinations, about sixteen in number, reaching nearly three-fourths the distance to the opposite margin, and with a slight curvature toward the base of the claw. The claws of the remaining legs are slender, strongly curved at the base, more moderately beyond, and again more strongly toward the sharply-pointed tip. On the whole the claw of II has the more pronounced curvature and is shortest, IV the 
least pronounced and is longest. Each has a very inconspicuous tooth in the middle of the flexor margin.

'The genital area is circular in general outline and is situated toward the posterior end of the body. It includes a genital cleft, flanked on either side in the male by one genital plate, in the female by two. The genital plates of the male are each lunate in form and bear six acetabula placed in two groups with a moderate interval between. In the female a transverse division along this line separates each plate into two, of which the anterior is irregularly quadrilateral, the posterior roughly triangular in outline, each bearing three acetabula.

MEASUREMENTS OF SPECIMENS DESCRIBED:

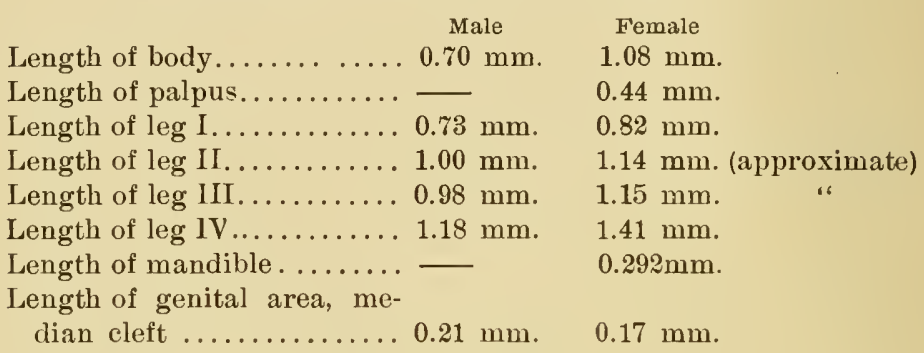

Types retained in the collection of the author.

This species was taken in the dredge at Lake St. Clair, September 1, 1893; later another was discovered in material collected a few days previous; and others were afterward collected in the vicinity of New Baltimore, Mich. Altogether six specimens were secured, but owing to breakage in transit of the bottle containing them, only two are available for description, and these, a male and a female, are to a certain extent distorted in mounting. Field notes taken at the time say: "Pinkish tinge to epimera and genital area. Legs and palpi blue of an unusally deep tint. Body deep olive brown, with a yellowishbrown Y-shaped mark. Eyes blackish."

\section{ATAX inTERMEdiUS KOENIKE.}

Atax ypsilophorus van Beneden, 48; 9 et seq., $\mathrm{Pl}$.

Atax Bonzi "living free," Koenike, 81a; 626.

Atax intermedius Koenike, 82; 265: Lampert, 93; LXXIX : Piersig, 94b; 214: Koenike, 96a; 233: Piersig, 96; 40: id., 97; Lief. I, 46, Pl. I, f. 2, a-e.

A. intermedius is one of the smaller species, and especially small are the males, between which and the females there is a much greater difference in size thaid in any other of our species. The length of several of 
each sex, measured from preserved specimens, proved to be from 0.75 to $0.95 \mathrm{~mm}$. for the females and only about 0.5 or $0.6 \mathrm{~mm}$. for the males.

The form is broadly oval, approaching elliptical, and with both ends evenly rounded. The skin shows a fine, even, parallel striation over the whole body of the female; the striae running transversely, while the epimera show the hexagonal reticulation which is characteristic of the group of species which has been referred to as the intermedius group. In the male the same reticulation is visible over the whole body, but is more pronounced and regular on the epimera.

Eyes large and rather distant from each other.

Maxillary shield relatively broad, especially posteriorly, where its thicker portion is evenly rounded, while the thinner and relatively slender ancoral process extends posteriad a short distance and ends in a broad tip, which is produced laterally to an unusual degree, forming recurved hooks. Line of separation between the two plates of which the shield is composed distinct.

Mandibles quite typical in form, the basal segment rectangular, broader posteriorly, with the dorsal posterior angle rounded, ventral posterior angle produced and a shallow mandibular groove on the ventral side. Distal segment moderate, claw rather small and slender, and moderately curved.

The palpi are as a whole quite slender, being only a little thicker than the first pair of legs, and in many respects are characteristic. The basal segment is not unusual; but 2 is much longer along the dorsal margin than along the ventral, the former being moderately convex, the latter nearly straight. It bears on the outer side and near the dorsal margin three long slender spines, two close together near the middle, a third toward the distal margin; on the opposite side are two spines near the middle. 3 is nearly straight along the dorsal margin, slightly convex along the ventral, and about half as long and two-thirds as thick as 2; it bears a long, slender spine on the outer side close to the proximal margin, and one on the inner side, close to the distal margin and also to the dorsal surface. 4 is the longest of all, yet only half as thick as 2; its dorsal margin is slightly convex toward the base and nearly straight beyond; its ventral surface is concave proximally, but convex distally where it bears the usual number of papillæ, of which the paired ones are characteristic. The outer of the two is short and inconspicuous, the inner very large, prominent and flattened laterally; in the male the latter is longer and slenderer, while the former is also longer. Both bear small hairs. Segment 5 is curved ventrad and is nearly circular in cross-section at the base, but at the tip is compressed laterally; it bears the usual terminal claws, which, however, are only moderately large and the whole segment is unlike that in the other species grouped with this.

Epimera in the female occupying about the anterior half of the rentral surface, in the male nearly the whole of it, leaving only room posteriorly for the genital area. Spaces between the groups also much wider in the female than in the male. In the former the first epimeron is nearly rectangular, and II irregularly triangular, with the inner end produced and 
passing beneath the anterior margin of III. Of the posterior group, III comprises about one-third and the suture between it and IV runs obliquely inward and forward half way to the inner margin. Anterior margin slightly concave, inner and posterior slightly convex, with inner posterior angle rounded and those of opposite sides diverging. In the male all the epimera relatively much larger and the inner ends of the anterior groups nearly in contact. The posterior groups are not only nearly in contact but a chitinous bridge connects the two which thus become one mass which is somewhat emarginate posteriorly.

The legs are all longer than the body in the female and very much longer in the male. III is the shortest, I next longer, II next and IV the longest of all. They are of medium stoutness and taper slightly from base to tip. In I and II the three outer segments are, in order of length, beginning with the longest, 4, 5, 6; in III all are nearly equal, but 5 exceeds 4; and in IV, 6 is also longer than 4. The spines are moderately numerous on the legs of the female and are rather long, while those on 2, 3 and 4 of I are set into short excavated papillæ similar to those of $A$. crassipes, though not so prominent. A bunch of four or five spines on the proximal half of the ventral surface of I 4 is noticeable. On the ventral surface of 4 and 5 of both III and IV, there are numeros hairs, more abundant and smaller on IV than on III, longer at the tip of each than elsewhere. The legs of the male posess fewer spines than do those of the female, and in this sex IV is peculiar; 4 of this leg is curved, the concavity being on the posterior and ventral aspect of the segment, and at the tip on the same aspect is a buncli of very long spines. On the posterior surface of 5 and about the middle is a bunch of strong, feathered spines. The claws are similar in form to those of A.ypsilophorus, and as in that species, are received into a cleft in the end of the dilated tip of the segment.

The genital area is proportionately large and flanked in the male by one plate on each side, in the female by two. Each of the two in the male is broadly lunate in form and bears five acetabula in two groups-2 and 3 respectively-and numerous small spines. In the female the anterior plate on each side is rhomboid in shape, with the anterior and outer margins slightly convex, and the posterior concave; it bears two acetabula, which are larger than those of the male, and its inner margin is reflected outward, forming two blunt, moderately thick lips, the margin of each of which bears two short stout spines. The posterior plate is roughly circular with a projecting inner anterior angle and its anterior and inner margins are thickened, the inner also reflected, forming a broader and less prominent lip than that of the anterior plate, while at the inner anterlor angle is a stout spine, and external to it on the anterinr margin a second. On this plate are three acetabula. 
MEASUREMENTS:

\begin{tabular}{|c|c|c|}
\hline & Male & Female \\
\hline Length of body. & $0.501 \mathrm{~mm}$. & $0.752 \mathrm{~mm}$. \\
\hline Length of $\operatorname{leg}$ I.. & $0.643 \mathrm{~mm}$. & $1.112 \mathrm{~mm}$. \\
\hline Length of leg II. & $0.852 \mathrm{~mm}$. & $1.607 \mathrm{~mm}$. \\
\hline Length of leg III & $0.627 \mathrm{~mm}$. & $0.959 \mathrm{~mm}$. \\
\hline Length of leg IV & $0.867 \mathrm{~mm}$. & $1.571 \mathrm{~mm}$. \\
\hline Length of palpus & $0.214 \mathrm{~mm}$. & $0.337 \mathrm{~mm}$. \\
\hline
\end{tabular}

Of this species, 13 specimens were obtained at L. St. Clair, Ang: 17, 1893, from Anodonta ovata and Oct. 10, 1893, 22 specimens were collected at Lansing, Mich., from mussels taken from Cedar River, but unfortunately the record of species of Unionidæ has been lost. It was found in considerable abundance at Round Lake, Charlevoix, Mich., in Anodonto subcylindracea, A. footiana, A. edentula and Unio luteolus; at " 26 " and Twin Lakes, in $A$. edentula, $A$. footiana and $A$. fragitis, in limited numbers in the former but more abundantly in the latter lake; and at Intermediate Lake, in Margaritana rugosa, Anodonta subcylindracea, A. footiana, A. edentula and A. fragitis, but in none common. At Beaver Island, Lake Michigan, it was collected rather commonly in Anodonta footiana and $A$. marryatana taken from a lake towards the south end of the island. At Grand Rapids, Mich., during the sumner of $1895, A$. intermedius was found only in Margaritana migosa from two localities on Grand River and only in limited numbers, while during the past summer the same was found to hold true. A few specimens were secured Aug. 17th to 20th, 1898, at White Lake, Muskegon County, Mich., from Anodonta footiana and A. subcylindracea.

In Nebraska it is a very abundant form, and on one occasion a very large Anodonta plana was fouud to contain 406 specimens. It has been collected in ponds at Lincoln, in Weeping Water Creek at Weeping Water and in the Blue River at Milford, from Unio subrostratus (once), U. Jamesianus (once), Margaritana complanata (occasionally), Anodonte plana, A. decora and $A$. grandis. The females are almost uniformly in excess, averaging three to each male; of 1178 specimens from the vicinity of Lincoln for example, 275 were males and $\$ 93$, 
females. There is usually a tinge of blue in the Michigan specimens, lacking in those from Nebraska.

\section{Atax abnormipes Wolcott.}

Atax abnormipes Wolcott, '98; 280.

Among the species to be considered in this paper are two which are quite different from all others, which bear a very close resemblance to each other and which are yet clearly distinct. They are both peculiar in the possession by the males of a lighly modified fourth pair of legs, while the females present no marked structural peculiarity. The first of these is Atax abnormipes. It is one of the smaller species, the females averaging about $0.7 \mathrm{~mm}$., the males about $0.55 \mathrm{~mm}$. The body of the former is about one-sixth longer than broad, somewhat broader posteriorly and so slightly pyriform in shape and evenly rounded at both ends. In profile it is about two-thirds as high as long, flattened dorsally in the center, the outline descending abruptly at either end. The surface of the body is marked by lines dividing it into minute hexagonal areas, appearing facetted. The male is decidedly pyriform, witl a breadth equal to fourfifths its length, the average of a number of specimens being $0.445 \mathrm{~mm}$. and $0.56 \mathrm{~mm}$. respectively. The body is smoothly rounded anteriorly, but deeply emarginate posteriorly.

Eyes very large, in the male measured, $0.143 \mathrm{~mm}$. apart. Each lens nearly circular, the anterior a little the larger.

Maxillary shield,-Comparatively broad, the sides anteriorly nearly parallel, with the anterior lateral angles diverging. The ancoral process very broad with a width at the tip of over half the extreme breadth of the whole, inconspicuously hooked and with sides which from the tip di. verge at once to the posterior lateral angles, wlicl thus instead of appearing posterior, seem like projecting angles in the middle of each side.

Mandibles.-The basal segment is broadly rectangular, nearly as broad as long, slightly narrowed anteriorly, the dorsal posterior angle rounded, the ventral angle produced for attachment of muscles. Distal segment comparatively large, the claw rather heavy, slightly curved and quite blunt. Patch of oblique striae near its base sharply limited and with a broadly elliptical outline.

Palpi.-Whole palpus slender and somewhat less than one-half the length of the body. Basal segment short, while 2 is of moderate length, relatively thicker than the rest, and convex along both extensor and flexor margins, the convexity of the former the greater; on the outer side are two long, tapering, slightly curved spines toward the extensor margin; on the inner surface one, similar to the others, in the middle, and a second close to the distal margin. 3, somewhat narrower than 2 and proportionately ong, though hardly as long as broad; flexor margin nearly straight; extensor margin convex; a spine at the proximal margin of outer surface, nearer the extensor side, and another at the distal margin on the inner side. 4, long and slender, narrower than 3, about three times as long as thick and slightly tapering toward the end; paired papillæ on the flexor 
margin two-thirds the way towards the tip, short, and with a slender spine, the third at the distal margin short and inconspicuous. 5, broad, laterally quadrate in outline, with the ventral distal angle produced and on the distal margin two slender, strongly curved claws, one near the extensor margin, the other about in the median line.

Epimera large, covering most of the uuder surface of the body and with a very narrow space between II and III and between those of oppo. site sides. I, rather broad, with parallel margins, the anterior margin concave, the posterior slightly convex. II, slightly broader than I and with its posterior margin quite convex and forming with the inner end of I a continuous curve. Line of separation between III and IV distinct onehalf the way in from the lateral margin and one-fourth the distance from the anterior towards the posterior margin of the plate formed by the two. Anterior margin of III concave and anterior internal angle projecting. Posterior margin of IV strongly convex, indistinctly angulated, and produced backward to a point even with the genital area, which thus lies in an angle between the last two epimera. Lateral margin deeply excavated between the points of articulation of legs III and IV and opposite the division between the corresponding epimera. The surface of the body between the four groups of epimera is thickened and so to a certain ex. tent all are fused into one mass. The surface of all the epimera is marked, as is the rest of the body surface, by a system of lines cutting it up into small hexagonal areas, and the same is true of the maxillary plates.

Legs.-In the male, rery short and comparatively thick, the last especially so. I averages one-seventh shorter than the body and is shortest of all, III is one-seventh longer than the body, II a sixth longer and IV a fourth longer. Of the individual segments, 1 is shorter, 2 and 3 are about equal and next longer; 4 is longest except in IV where 6 is very long, exceeding it and all the others; while in I and II, 6 exceeds 5 and in III the reverse is true. The legs are all moderately well supplied with spines and are not noteworthy except in the case of III, 5 and IV, 4 to 6 . The former has at its tip three doubly curved blade-like spines reaching three-fourths the way to the end of 6 . Of the latter, IV 4 is compressed laterally through the distal two-fifths of its length and on this compressed portion bears a bunch of six very large spines, placed in two rows on the ventro-anterior surface, and exceeding in length the next segment, while on the posterior surface are about nine spines, of which six are moderately stout, while the three distal are very long and slender and reach beyond the distal end of 5 by about one-third its length. 5 is short, at its base narrower than 4, tapering toward the tip, with two very heavy, curved blunt spines on the extensor surface and a row of spines along the flexor side, and a bunch of fine hairs at the distal end, while 6 is very slender and rather long. All the claws are strongly bent and bifid, with an accessory tip on the convex side short and inconspicuous and ending at a distance from the end equal to one-sixth the whole length of the claw. 
The legs of the female are slenderer and relatively shorter and III much shorter than in the male. IV, 4 is exceeded by both 5 and 6 . There is no marked structural peculiarity; the segments of the last pair decrease regularly in thickness from 1 to $6 ;$ IV 4 lacks the six large spines; and IV 5 the two long ones, retaining the row of spines on the flexor surface.

The genital area of the male lies one-half on either side of the groove in the emarginate posterior end of the body, the opening being at its bottom; the latter is bounded by two rather broad lunular plates, each with five acetabula in two groups-two in front and three behind. In the female a transverse division indistinctly separates each of these lunules into two parts, the anterior with two, the posterior with three acetabula, and each bears at the angle adjacent to the other three, a flattened spine.

MEASUREMEÑTS :

\begin{tabular}{|c|c|c|}
\hline & Female & Male \\
\hline Length of body. & $0.714 \mathrm{~mm}$. & $0.586 \mathrm{~mm}$ \\
\hline Length of leg I. . & $0.560 \mathrm{~mm}$. & $0.510 \mathrm{~mm}$ \\
\hline ength of leg II.. & $0.740 \mathrm{~mm}$. & $0.688 \mathrm{~mm}$. \\
\hline Length of leg III. & $0.663 \mathrm{~mm}$. & $0.668 \mathrm{mr}$ \\
\hline Length of leg IV. & $0.770 \mathrm{~mm}$ & $0.745 \mathrm{mv}$ \\
\hline alpus.... & $0.306 \mathrm{~mm}$. & $0.265 \mathrm{~mm}$ \\
\hline andible. & $0.173 \mathrm{~mm}$. & 0.153 \\
\hline
\end{tabular}

Types in the author's collection; co-types have been deposited in the collection of the Zoological Laboratory, University of Nebraska, in the Museum of Comparative Zoology, of Harvard University, in the United States National Museum, and in the Kgl. Museum für Naturkunde in Berlin.

Atax almormipes was collected at Lake St. Clair during the summer of 1893 , but owing to confusion of different species due to lack of familiarity with the group, no statement can be made as to the hosts except that it was almost surely harbored by Unio alatus, $U$. ventricosus and $U$. luteolus. It was next met with at Grand Rapids, Mich., in the summer of 1895, when individuals were found in $U$. ligamentinus, $U$. occidens, $U$. ventricosus (very abundant), $U$. alatus and $U$. rectus from different localities in Grand River, while collections made since have added to the list of hosts $U$. undulatus, and emphasized the fact that it is far more abundant in $U$. ventricosus than in any other species of mussel. One specimen was found in that species from Rogue River, Kent County, Mich., July 5, 1897. It has been taken in limited numbers in $U$. luteolus from Reed's Lake near Grand Rapids, Mich., in the same Unio from Long Lake, Kalamazoo, Mich., and in that and $U$. ventri- 
cosus, from Black Lake, Holland, Mich., while the past summer it was found in $U$. luteolus from White Lake, Muskegon County, Mich.

At Oshkosh, Wis., the species was found during September, 1897, in $U$. gracilis and $U$. luteolus from Lake Winnebago. In Illinois, as determined from specimens received from Prof. H. M. Kelly and Mr. M. Ricker, A. abnormipes has been taken from $U$. anodontoides, $U$. gracitis and $U$. occidens collected at Havana. Finally in material received from Mr. R. H. Johnson and obtained at Chautauqua Lake, N. Y., it occurred in $U$. luteolus and $U$. phaseolus and perhaps in Anodonta plana, though the record is doubtful, while it also was present in mites taken from $U$. ventricosus at Cheektowaga, Erie County, N. Y.

\section{A. INDISTINCTUS WOLCOTT.}

Atax indistinctus Wolcott, 98; 281.

The second species of Atax referred to under the head of the preceding is $A$. indistinctus, which received the name it bears when only females had been collected, and in reference to the close resemblancc between the females of the two species, which were only separated by the most careful observation. Since the preliminary paper in which this was described has been published an abundance of males have been secured and the species shown to be entirely distinct though closely allied.

A. indistinctus is a species rather under medium size and yet a little larger than A. abnormipes, the measurement of several males showing a variation in body length of from $0.675 \mathrm{~mm}$. long by $0.55 \mathrm{~mm}$. broad to 0.75 $\mathrm{mm}$. long by $0.618 \mathrm{~mm}$. broad, while the average of a number of females was $0.825 \mathrm{~mm}$. by $0.63 \mathrm{~mm}$. It is similar in form to $A$. abnormipes, and like that species the whole surface of the body is marked off by fine lines into small hexagonal areas.

Eyes large but not quite so large as in the preceding species, and about the same distance apart.

Maxillary shield similar to that of A. abnormipes, but the posterior lateral angles not so prominent and the sides in front of it slightly diverging instead of parallel. Rostrum rather prominent.

Mandibles similar to those of $A$. abnormipes in form.

Palpi rather slender but not so much so as in those of the previous species. The spines are similar in number and position to that form, the two on the outer side of 2 dividing it into thirds. The distal margin of this segment is not uniformly concave but a shallow re-entrant angle separates the extensor two-fitths and the flexor three-fifths of its length. A rounded angle in the proximal margin of 8 corresponds to this, the segment being proportionately heavier than in the allied species, while 4 is 
also proportionately stouter and more tapering, its base being nearly as thick as that of 3 , while the distal end is only one-half as thick as the proximal; its breadth in the middle is a littleover one-half its length. The papillae on this segment are rather more prominent than in A. abnormipes. 5 is similar to that of that species but the claws are more slender and a little farther apart, and the ventral distal angle a little more produced.

Epimera.-Of the same general character as in A. abnormipes, but differing in the following respects: 'They occupy sligatly less than a proportionate amount of the ventral surface; the space between the groups of epimera is a little greater and the inner ends of the first pair do not approach closely to each other but leave a considerable interval behind the maxillary shield. This is owing to a shortening of I and is accompanied by an increase in the curvature of the posterior margin of the plate formed by it and II, which margin is also indistinctly angled toward the base of II. The posterior margin of IV does not project so far posteriorly and so the genital field is not to such an extent enclosed by it.

Legs of female relatively longer than in A. abnormipes and very slightly more slender. I is one-tenth shorter than the body, II and III about one-fifth longer and of the two, II a tritle the longer, IV two-fifths longer than the body. Individual segments of each leg in order of length $4,6,5,3,2,1$, except in IV, where the last three are $6,5,4$. Number and distribution of spines on the legs about the same as in A. abnormipes; a row of long spines on the flexor surface of segments 4 and 5 of leg IV; the tip of 5 in each leg armed by several long spines.

In the male, I slightly exceeds the body-length; II, III and IV are each a little over two-fifths longer, and of these IV is slightly longer than II and that slightly longer than III. Segments in I and II, in order of length 4, $6,5,2,3,1$; in III, 5 is longer than 6 , and in IV, 6 is less than 2 or 3 , this shortening leading to a shortness of the whole leg. The same three spines are present at the distal end of IV 5, but are not so long-not quite two-thirds the length of 6 . IV modified in a similar manner to the same in A. abnormipes, but differing in the following details: Spines on 3 much more numerous; on the posterior surface of 4 the spines are longer and more numerous, and on the ventro-anterior surface are eight spines, three in a dorsal and five in a ventral row; the distal portion of this segment is not so much compressed, and the ventral surface is quite evenly convex; 5 is thicker, has a row of ventral spines as in $A$. abnormipes but only one long heavy spine in the middle of the dorsal surface instead of two. Claws similar except that the accessory tip is one-third the length from the end of the principal one.

Genital area as in $A$. abnormipes in form except that the angle which separates the plates of the two sides anteriorly is more acute here than in A. abnormipes. Acetabula in males usually seren on each side-in one specimen eight-with an indefinite separation into two groups. In the female are three and six on the two plates of either side, in one case four and five on one side and three and six on the other. 
MEASUREMENTS:

\begin{tabular}{|c|c|c|}
\hline & $\begin{array}{l}\text { Male } \\
0.740 \mathrm{~mm} \text {. }\end{array}$ & $\begin{array}{l}\text { Fema } \\
0.867 \mathrm{~mm} \text {. }\end{array}$ \\
\hline Vidth of body (extres & $0.637 \mathrm{~mm}$ & \\
\hline ength of leg I......... & $0.785 \mathrm{~mm}$. & $0.698 \mathrm{~mm}$. \\
\hline $\begin{array}{l}\text { h of leg II.. } \\
\text { h of leg III }\end{array}$ & $1.066 \mathrm{~mm}$, & $0.890 \mathrm{~mm}$. \\
\hline $\begin{array}{l}\text { ength of leg III } \ldots \ldots \\
\text { ength of leg IV } \ldots . .\end{array}$ & $\begin{array}{l}1.050 \mathrm{~mm} . \\
1.076 \mathrm{~mm} .\end{array}$ & $\begin{array}{l}0.870 \mathrm{~mm} \text {. } \\
1.020 \mathrm{~mm}\end{array}$ \\
\hline
\end{tabular}

Palpus (from another speci-

men of same size in case

of male) ............. $0.347 \mathrm{~mm} . \quad 0.380 \mathrm{~mm}$. (approx.)

Types in the author's collection; co-types have been deposited in the collection of the Zoological Laboratory, University of Nebraska, in the Museum of Comparative Zoology of Harvard University, in the United States National Museum, and in the Kgl. Museum für Naturkunde in Berlin.

Specimens of females of this species taken at Lake St. Clair, Mich., were confused with the following species and their identity not detected till mounted and subjected to a careful microscopical examination, when the differences between the two species became apparent. Hence no statement can be made as to the definite source of the specimens.

It was therefore with much pleasure that upon looking over the collection of mites from Prof. H. M. Kelly, this species was found in considerable numbers-60 males and 115 females altogether. They were taken from $U$. alatus and $U$. gracitis from the Illinois River at Havana, Ills.; from $U$. gracilis from the Spoon River at Duncan's Mills and Bernadotte, Ills.; and from "Unio spp." from the Cedar River at Mt. Vernon, Iowa. Specimens were also found in the material from $\mathrm{Mr}$. M. Ricker.

\section{ATAX SERRATUS WOLCOTT.}

Atax serratus Wolcott, 98; 282.

Atax serratus resembles very closely the two preceding species in the appearance of the palpi and in the form of the claws and to a lesser degree in the outline of the genital field and of the epimera. It is larger, proportionately more elongated and the body of the male is only slightly pyriform. The legs are proportionately shorter and IV of the male is not modified. They are characterized by the presence of numerous serrate spines which suggests the specific name proposed.

The body is oval in form, bluntly and evenly rounded at both ends in the female, that of the male with a slight posterior emargination. Its 
extreme width at a point a short distance beyond the middle is equal to two-thirds of the length; from the side the dorsal convexity is seen to be considerable and quite uniform, but highest posteriorly. Its surface is ' smooth and without chitinous thickenings or lines of any kind, though the epimera show the regular reticulation referred to in regard to the two preceding species.

Eyes as in the two preceding forms, large and deep black in color, though a little farther apart than in the others.

Maxillary shield similar to that of the preceding; suture between the two plates running about half way forward from the posterior end and a little farther than even with the posterior lateral angles.

Mandibles.-Ventral margin nearly straight; dorsal parallel to it, curving outwardly however toward the posterior end, and this curve continued evenly around the posterior end to the produced posterior ventral angle. Distal joint medium in size and not noteworthy as to form; claw slightly curved, and concave margin slightly arched outwardly in middle.

Palpi large and heavy, similar to those of the preceding in form. Convex dorsal margin of 2, two and a half times the length of the nearly straight flexor margin and 2 one-third as broad as the length of the whole palpus; there are two spines near the middle of its outer surface, one on the inner near the middle and another near the distal margin which is llat, blade-like and serrate. 3 very broad, its breadth four-fifths that of the preceding and one-half its length; inner margin one-half of outer and both nearly straight. 4 thick, considerably tapering, at the base twothirds as broad as 2 and at the tip less than one-fourth as broad. Paired papillae three-fourths the distance to the distal end. 5 has the inferior distal angle produced and a spine at the base of the projection on the outer side.

Epimera occupying two-thirds of the ventral surface, with the spaces between the groups narrow; the inner ends of the anterior groups approach each other much closer than in the preceding, and the posterior margin, instead of being smoothly rounded, shows an excavation opposite the junction of the two epimera. Anterior median angles of posterior groups produced, anterior margin concare; the inner margins diverging posteriorly; the posterior median angles rounded off; and the posterior margin convex, but only moderately so. Suture separating III and IV nearly complete.

Legs moderately heavy, rather more slender than in the other two species and proportionately shorter, while the species is peculiar in the fact that III is longer than II. In the male I equals about three-fourths the body length, II is somewhat shorter than the body, III about equal to it, while IV, which is shortened, is only one-tenth longer. In the female, all the legs are relatively shorter still and IV is scarcely longer than the body. Length of individual segments in order, beginning with the longest, $4,5,6,2,3,1$, except in III where 5 is about equal to 4 and in IV of both male and female where 5 is greater than 6 and that than 4 . In the female more or less of the spines on the legs are serrate along both 
margins, those on only the basal segment of I, but gradually including more and more on each leg, till on IV are serrate spines on all segments, and on the distal is a row of very prominent, flattened, blade-like, serrate spines. On IV 4 are also three heavy club-shaped spines. In the male serrate spines are present, but less numerous and not so prominent, while the sex is characterized by not only the shortening of the last pair of legs but also by a thickening of the same making them stouter than the two preceding pairs and about as stout as the first. The claws are sharply curved, have an accessory tip at two-thirds the distance from the base, and end in a very fine point.

Genital area broader than long, each lateral plate divided in the female into two, an anterior pouch-shaped plate with its inner end produced into a long neck, curved backward and bearing on its tip a flattened spine, and a posterior nearly circular plate. Three specimens examined possessed the following number of acetabula: 15 and 31 on one side, 12 and 25 on the other; 11 and 21 and 12 and $19 ; 8$ and 12 and 6 and 17 . The male has but a single plate on either side with a total of 19 or 20 acetabula on each side.

MEASUREMENTS:

\begin{tabular}{|c|c|c|}
\hline oI Doo & $\begin{array}{c}\text { Male. } \\
0.868 \mathrm{~mm} .\end{array}$ & $\begin{array}{r}\text { Female. } \\
1.170 \mathrm{~mm} .\end{array}$ \\
\hline of $\operatorname{leg} \mathrm{I}$. & $0.668 \mathrm{~mm}$. & $0.816 \mathrm{~mm}$ \\
\hline th of leg II. & $0.820 \mathrm{~mm}$. & $1.020 \mathrm{mn}$ \\
\hline th of $\operatorname{leg}$ III. & $0.870 \mathrm{~mm}$. & $1.070 \mathrm{mr}$ \\
\hline th of $\operatorname{leg}$ IV.. & $0.959 \mathrm{~mm}$. & $1.214 \mathrm{n}$ \\
\hline
\end{tabular}

Color of legs, a bright blue-green, and body tinged with bluish-green.

Types in the author's collection; co-types have been deposited in the Zoological Department, University of Nebraska, in the Museum of Comparative Zoology of Harvard University, in the United States National Museum, and in the Kgl. Museum für Naturkunde in Berlin.

Of A. serratus, specimens have been collected at L. St. Clair, probably from Unio luteolus. At Grand Rapids, Mich., specimens have been obtained from Unio cocciners, $U$. undulatus and $U$. alatus from Grand River, and from Margaritana deltoides from Rogue River, Kent County, Mich. In material from Unio occidens from Cayuga, Cheektowaga, Erie County, N. Y., one specimen was found, while specimens have been secured amongst a number of mites from "Unio spp." collected in the Cedar River, Mt. Vernon, Iowa. It is thus a widely distributed species, though one of the rarer ones. Owing

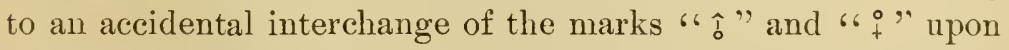
the labels of two slides and the distraction of numerous interruptions when the preliminary description of this species was 
written, confusion occurred in that description and so it is in certain particulars wrong. Unfortunately too, and much to the writer's regret, the error was overlooked in the reading of proof and only discovered after the separates were distributed.

\section{ATAX FOSSULATUS KOENIKE.}

Atax fossulatus, Koenike, 95b; 221, Pl. III, f. 68-70: Wolcott, 98; 283.

A. fossulatus is one of the larger species of the genus, the males ranging in length from $1.1 \mathrm{~mm}$. to $1: 3 \mathrm{~mm}$., the females from $1.4 \mathrm{~mm}$. to $1.6 \mathrm{~mm}$. The body is oval, smoothly rounded anteriorly and posteriorly and with the greatest breadth abont opposite the posterior margin of the last epimera: dorsally it is considerably arched, somewhat ligher posteriad.

The eyes are moderately large and quite close together, in onc male specimen $1.08 \mathrm{~mm}$. long, the longest diameter of the cye amounting to $0.046 \mathrm{~mm}$, and the distance between the inner borders of the two to 0.224 $\mathrm{mm}$., while the cxtreme width of the body is $0.718 \mathrm{~mm}$.

Maxillary shield broad, the sides anteriorly nearly parallel, the lateroposterior angles moderatc and the shield contracted posteriorly to a rather broad and short ancoral process the width of which is two-sevenths the greatest width of the shield.

Mandible with basal segment roughly rectangular, broadened posteriorly, the dorsal and posterior margins forming, by the rounding off of the posterior dorsal angle, a sweeping curve. Total length in the specimen referred to above, $0.28 \mathrm{~mm}$. and greatest width somewhat more than half the length. Distal joint moderate in size and with the claw comparatively short and straight, slightly hooked at the tip; the area of crossstriae on the side of the base of the claw comparatively restricted.

Palpi rather large and moderately heavy, in the specimen referred to previously the lengtl amounting to $0.607 \mathrm{~mm}$., while the maximum dorso-ventral diameter of segment 2 is $0.184 \mathrm{~mm}$. Segment 2 is convex on both dorsal and ventral margins, but the dorsal curature is much the greater; it is but little longer than thick, and bears on both outer and inner surfaces two spines, those of the outer side close together midway between the two ends and near the dorsal margin, those on the inner side also close together, slightly farther from the base and more removed from the dorsal margin. 3, about two-thirds as thick as 2, one-half as long, and with a spine at the proximal margin on the inner side and another toward the distal margin on the outer side. 4, slightly longer than 2, slightly less than one-half as thick; the dorsal and ventral margins nearly parallel to the base of the paired papillae on the ventral surface, beyond which the thickness of the scgment rapidly diminishes. All segments showing a gradual tapering when viewed from above. The outer of the paired papillae is very small, the inner more prominent and the spur at the distal margin moderately so. 5, nearly straight above, concave below, tapering to a blunt tip, which bears three small blunt claws; on the ventral margin, midway between base and tip, a small hair. 
Epimera covering approximately the anterior half of the rentral surface of the body, the spaces between the two groups on either side comparatively narrow, that between the groups of opposite sides greater, especially in the case of the anterior groups, between the inner ends of which is quite an interval. The spaces are all wider in the female and in that sex the epimera are relatively a little smaller than in the male. The last epimera are relatively long, being longer than broad, while just external to the inner posterior angle the posterior margin bears a spur-like projection which curves outwardly and probably serves as a point of muscle attachment. III, broadened externally, and an excavation on the outer margin corresponding to the suture between it and IV.

Legs rather long and slender, the first considerably stouter than the others; the first pair of the female nearly three-fourths the body length, II seven-eights of that length, III slightly exceeding the length of the body, and IV nearly a fourth longer. In the male the legs are proportionately still longer, all exceeding the length of the body, I by a very lit. tle, IV by over two-thirds. Of the individual segments, 4 exceeds 5 and that 6 , except in III, where 5 is longer than 4 , and in IV where 5 is still more elongated and 6 greatly lengthened, slightly exceeding 5 . The segments gradually decrease in thickness from 1 to 6 and the last tapcrsconstantly from base to tip. The legs are armed with a considerable number of spines of medium length, which form a continuous row along the ventral surface of segments 4 and 5 , and also along 6 in the case of $I V$, the spines in this last case shorter. The distal segment is unusually contracted toward the tip, and is not cleft to receivc the claws, but these last are partly covered by a thin chitinous plate, which, together with several slender hairs, springs from the dorsal side of the segment behind the claws. The claws are bifid, a small accessory claw being developed on the dorsal side of the primary one very close to the tip, except in the case of the first leg, where the secondary claw is longer and springs from a point one-third the way back from the tip of the other. The claws, as a whole, are rather heavy and strongly curved.

The genital area is situated about midway between the last epimera and the end of the body, slightly nearer, perhaps, to the latter. It is broadly oval in form and nearly as broad as long. In the male the genital cleft is flanked by two reniform plates, which bear five large acetabula, of which the two anterior are in contact, the second separated by a narrow interval from the third, the three posterior in contact, and the two last situated side by sile; several short spines are found along the inner margin of these plates. In the female the five acetabula bear the same relationship to one another but the two platcs are not so erident and the acetabula seem to be set into the surface of the body itself, though this is thickened over the whole by a deposition of chitin. At the genital opening, short clefts in this thickened area run toward either side and in the four angles formed by these and the genital cleft itself, are four short, stout, curved spines, while other smaller spines occur here and there. scattered over the space within the row of acetabula and along the margin of tie genital cleft. 
MEASUREMENTS:

Male

Female

Length of body.............. $1.136 \mathrm{~mm}$.

$1.419 \mathrm{~mm}$.

Length of $\operatorname{leg}$ I.............. $1.188 \mathrm{~mm}$.

$1.035 \mathrm{~mm}$.

Length of leg Ii .............. $1.515 \mathrm{~mm}$.

Length of $\operatorname{leg}$ III . . . . . . . . . . $1.647 \mathrm{~mm}$.

Length of $\operatorname{leg} I V \ldots \ldots \ldots \ldots \ldots \ldots 1.958 \mathrm{~mm}$.

$1.285 \mathrm{~mm}$.

$1.438 \mathrm{~mm}$.

$1.739 \mathrm{~mm}$.

This species was the most abundant of all at Lake St. Clair, 228 specimens being secured from a number of species of Unionidæ, but no definite statement of the exact species in which it was taken can be given, except that among them were $U$. alatus, $U$. ventricosus and $U$. luteolus.

Specimens were secured at Charlevoix, Mich., and vicinity, as follows: in Round Lake, from Anod. subcylindraceu, $A$. footiana and U. luteolus; in " 26 " and Twin Lakes from the sane Anodontas and $A$. edentula and $A$. fragilis; in South Lake, Beaver Island, Lake Michigan, from $U$. luteolus. Nowhere else has this species been found in Anodontas, and I should be tempted to believe that those collected had nigrated from Unio luteolus while the inussels were kept in pails of water a day or two before being exanined, were it not that at Twin Lake only Anodontas were collected. The species was rare at all of these localities.

At Grand Rapids, Mich., A. fossulutus has been found very generally distributed, _in Unio luteolus at Reed's Lake; in $U$. mbiginosus, I. plicatus, U. undulatus, U. pustulatus, U. Nonieboraci, U. occidens, U. ventricosus, U. ligamentinus, U. spatulatus, $U$. rectus, $U$. coccineus, $U$. verrucosus (especially abundant), U. ulatus, $U$. Schoolcrafti, from different localities in Grand River; and in U. occidens from Rogue River, Kənt County.

The species has also been taken at Lansing, Mich., but from what host is uncertain. At White Lake, Muskegon County, it was found the past summer in $U$. luteolu*, and at Black Lake, Holland, Mich., it has been collected from that species and from Lnio occidens.

At Oshkosh, Wis., it has been found in Unir gracilis and U. luteolus. 
It is present in the material from Illinois in $U$. alatus, $U$. asperrimus, $U$. cormutus, $U$. gracitis, $U$. pustulosus, $U$. plicatus and $U$. occidens from the Illinois river at Havana, and from U. gracitis, U. levissimus, U. lachrymosus, U. pustulosus and U.tuberculatus from the Spoon River at Duncan's Mills and Bernadotte. Also in materia! from the Cedar River at Mt. Vernon, Iowa, from $U$. rectus, $U$. alatus and others.

In New York it has been found at Chautauqua Lake in $U$. luteolus and at Cheektowaga, Erie County, in $U$. occidens.

\section{9. atax stricta Wolcott.}

Atax stricta Wolcott, 98, 283.

Very similar to the preceding in many ways but differing in details. It is smaller than $A$. fossulatus, relatively broader and the legs are not only slenderer and shorter, but have usually a blue tinge which is lacking in the other species.

Eyes small and rather distant from one another.

Maxillary shield and mandibles very similar to those of $A$. fossulatus.

Palpi slenderer than those of that species and with the last segment somewhat more strongly curved; ventral papillae on 4 relatively a little more prominent.

Epimera in general of the same form. They are, however, slightly broader proportionately, and the posterior median angle of IV is more rounded and not so strongly excavated.

Legs relatively shorter, more slender and not so tapering as those of the preceding species. I, not so noticeably stouter than the others and distal segment, instead of growing constantly smaller toward the tip, is narroved in the middle and dilated at the tip, which is even slightly broader than the base. As in $A$. fossulatus, 5 is relatively elongated on III and both 5 and 6 on the last pair of legs, and as in that species III is longer than II. Distal segments relatively longer on all legs and last segment flattened and very slightly dilated dorso-ventrally at the tip, instead of gradually contracted as in $A$. fossulatus. Claws all simple, relatively longer and more slender, and those on I stouter and not so evenly curved as those of the other legs. Not so many spines on the legs as in the allied form, but they are longer.

Genital area in about the same position as in the preceding but relatively smaller, the acetabula smaller, and intead of the last two being side by side they are all in one curved line. The two rows do not approach each other so closely anteriorly and posteriorly as in the other species. The sexes differ in a manner similar to those of $A$. fossulatus. 


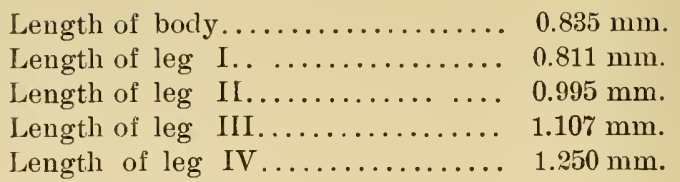

No female is in such a condition on the slide as to allow of ready or accurate measurement.

Types in the author's collection; co-types have been deposited in the Museum of Comparative Zoology of Harvard University, in the United States National Museum, and in the Kgl. Museum für Naturkunde in Berlin.

This species when collected was considered to be the male of A. fossulatus, but when slide-mounts of that species were made the true male was discovered, and also both sexes of the present form. The most striking difference, and that first noted, was in the position of the acetabula in one line, hence the name "stricta," but careful observation showed the presence of other differences as above indicated and also that these differences, though slight, were constant. It may be a variety of $A$. fossulatus, but it is for the present considered separate, though closely allied.

Specimens were taken at Grand Rapids, Mich., during the summer of 1895 , among $A$. fossulatus, from $U$. coccineus, $U$. ligamentinus, U. occidens, U. rectus, U.mubiginosus, U. Schoolcrafti, $U$. undulatus, $U$. vermocosus and $U$. alatus-89 specimens altogether-but owing to their being confused with $A$. fossulatus no statement can be made as to the exact source. Collections of many more of the same mussels from near the same localities, this last summer, it was hoped would give more definite information, but only one specimen was found, which was in $U$. undulatus.

In Nebraska it has been collected from U. Jamesianus and $U$. lachrymosus from pools near Lincoln, from $U$. undulatus, $U$. lachrymosus, U. mubiginosus and U. Jamesianus at Weeping Water, from Weeping Water Creek; and from $U$. lachrymosus from the Blue River at Milford. The Nebraska specimens are all peculiar in that the genital area is a little smaller and the 
acetabula smaller and more closely crowded toward the middle of either side.

Specimens were received from Prof. Kelly and Mr. Ricker collected in $U$. plicatus at Havana, Ills.

\section{ATAX aRCUATA WOLCOTt.}

Atax: arcuata Wolcott, 98; 284.

A species equal in size to $A$. fossulatvs and $A$. ypsilophorus, between which it a ppears to occupy an intermediate position, having resemblances to both, but quite distinct from either. It is especially eharaeterized by the form of the legs, the distal segments of whieh are so strongly curved as to suggest the name bestowed upon it.

It is of the same elongated elliptical form which characterizes the related species, very slightly broader posteriorly, and with both anterior and posterior margins evenly rounded.

Eyes very small and lenses nearly equal. In the male speeimen measured the two were $0.301 \mathrm{~mm}$. apart.

Maxillary shield similar to that of A. ypsilophorus, except that the ancoral process is not so long, and the lateral margins perhaps a little less dirergent anteriorly.

Mandibles of the same form as in that species except that a coneavity is present in the posterior margin toward the ventral angle, whereas in A. ypsilophorus the margin is nearly straight.

Palpi also very similar to those of $A$.ypsilophorus, though varying somewhat in the direction of those of A. fossulatus. 1, as heavy as in the former species, but 3 relatively less thick, and 4, instead of tapering. nearly as thick at its distal as at its proximal end, the ventral papillae being more prominent. Distal segment slenderer and longer than in $A$. yp silophorus and the claws at the tip relatively smaller.

Epimera.-Anterior groups narrower toward the median line and more nearly triangular than in either $A$. ypsilophorus or A. fossulatus. Posterior group much shorter than in either and inner margin distinctly shorter than the outer, with both anterior and posterior inner angles very much rounded, especially the latter, which causes the epimera of the two sides to appear widely divergent posteriorly. Space between the two groups of epimera on eaeh side very wide.

Legs very long, especially in the male, and similar to those of $A$. fossulatus in that 1 is very markedly thicker than the rest and in that the successive segments of each leg are distinctly slenderer than the one next the body and give an evident tapering appearanee. They are, howerer, relatively slender. III is a trifle longer than II, all but I exceed the body in length, and IV is over half as long again. Of the segments, 5 is in all legs unusually long and 6 abnormally short. The legs are less plentifully supplied with spines than are those of either of the other two species and the spines are rather weak, 'The legs are especially characterized by the eurved form of the terminal segment, the curvature being only moderate in the case of $\mathrm{I}$, but in IV amounting to a deflection of $30^{\circ}$. This 
segment also tapers toward the tip but just at the end is broadly expanded to receive the short thiek bifid claw, whieh is mueh smaller, broader and thieker than in $A$. fossulatus. The rounded margin of the expanded tip of the segment projeets above the claw beyond its base, and bears two short flattened laneeolate spines whieh projeet still farther.

Genital field similar in form to that of $A$. ypsilophorus though somewhat broader, being broader than long, like that of that speeies in position, and finally also flanked in both sexes by a single plate on either side, which bears in the male about 22 to 25 aeetabula, in the female 26 to 30 . These are not all of the same size and two a little before the middle and against the outer margin of the plate are deeidedly larger than the rest. Spines at the genital opening of the female similar to those of $A$. ypsilophorus, heary, eurved and flattened. A few small and weak spines are seen along the inner margin of eaeh genital plate.

MEASUREMENTS:

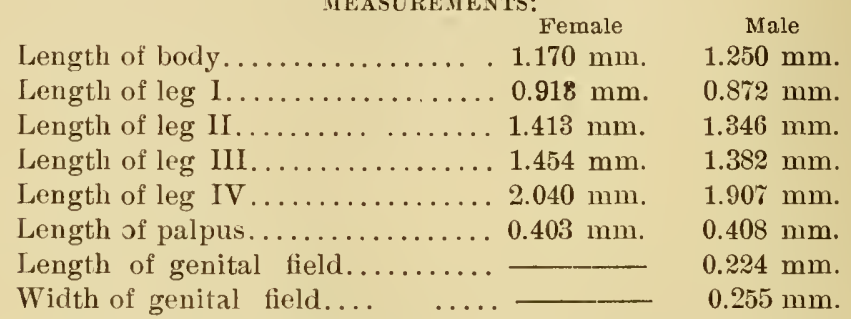

In color this speeies is not distinguishable from $A$. ypsilophorus.

Types in the author's eolleetion; eo-types have been deposited in the eolleetion of the Zoological Laboratory. University of Nebraska, in the Museum of Comparative Zoology of Harvard University, in the United States National Museum, and in the Kgl. Museum für Naturkunde in Berlin.

A. arcuata was first found at Charlevoix, Mich., in Round Lake and living in Anodontre subcylindracea, A. footiana and Unio luteolus. At " 26 " Lake it was collected in Unio luteolus. and at Intermediate Lake in Margaritana rugosa, A. subcylindracea, A. footiana, A. edentulu and A. fragilis.

At Grand Rapids, Miclı., it has been taken in Marg. deltoides, M. marginata and A. subcylindracea, and at Rogue River, Kent County, in A. subcylindrucer. At White Lake, Muskegon County, Mich., it has also been found common in A. subcylindracen and in all the collections referred to, far more specimens were taken in that than in any other mussel.

It has been collected in Marg. marginata from the Schuylkill River at Phœnixville, Pa., and specimens were received from Prof. Kelly. 


\section{ATAX YPSILOPHORUS (BONZ).}

Acarus ypsilophorus Bonz, 1783; VII, 52, Pl. I, f. 1-4.

Trombidium notatum Rathke, 1797; IV, 175, Pl. X.

? Hydrachna triangularis Say, 21; II, 79: id., Leconte's Ed., 59; II, 22. Limnochares anodontae Pfeiffer, 24; pt. 2, 27-28, Pl. I.

Hydrachna concharum von Baer, 27; XIII, 590, Pl. XXIX.

Unionicola oviformis, U. lactea, ? U. personata, ? U. humerosa, ? U. symmetrica, ? U. proxima, ? U. lugubris, ? U. unicolor, ? U. reticulataHaldeman, 42; 1-3, Pl., f. 1-11.

Non Atax ypsilophora von Beneden, 48; (=A. intermedius Koenike). Atax ypsilophora Garner, 64; 114: Claparède, 68; 474, Pl. XXXIII: Bessels, 69; 146: Lebert, 79; 367.

Atax ypsilophorus Neuman, 80; 26, Pl. I, f. 2: Koenike, 87a; 626: Haller, 81a; 78: Koenike, 82; 265: Leidy, 83; 44: Harrington, Fletcher and Tyrrell, 84; 140.

Atax concharum Krendowsky, 85; 59.

Atax ypsilophorus Barrois and Moniez, 87; 5: Girod, 89; XIV, n. 5, 107: Koenike, 91c; 257: Piersig, 94b; 214: Koenike, 95b; 217: Piersig, 96; 40: Koenike, 96; 232: Piersig, 97; Lief. I, 43. Pl. II, f. 3, a-h.

This, the best known of all the species of the genus and the one first described, is also one of its larger representatives, the males measuring from 1.1 to $1.3 \mathrm{~mm}$. in length, the females from 1.3 to $1.5 \mathrm{~mm}$., or when distended with eggs, $1.8 \mathrm{~mm}$. The body is oval, but more nearly elliptical than in most species, evenly rounded at each end, and much arched. The males are considerably slenderer than the females.

The eyes are proportionately small and moderately close together, in a specimen $1.086 \mathrm{~mm}$. long, $0.296 \mathrm{~mm}$. apart. They are brownish black in color.

The maxillary shield is widest anteriorly, quite evenly rounded posteriorly and with a prominent ancoral process, which is considerably broadened at the tip, each lateral corner of which is produced to form a recurved hook. The rostrum is moderately prominent. Mandibles relatively short and broad. in a specimen $1.32 \mathrm{~mm}$. long, their total length being $0.24 \mathrm{~mm}$. The basal segment is broadest posteriorly, where its width is over two-fifths the total length; its ventral sicle is nearly straight, with the posterior angle produced; its dorsal and posterior side form together a sweeping curve from near the anterior end on the dorsal side to the ventral posterior angle. The distal joint is rather heavy, but the claw is deeply inserted and the exposed portion is relatively short and slender, and quite straight. The area of oblique striae is rhombic in outline and confined to the base of the claw, which is bent at a point eren with the distal margin of the segment, and ends in a sharp point.

Palpi.-Comparatively small and only moderately thick. The first segment is narrow, and 2 is wide, being twice as wide as 1 , and wider than long, measured from the middle of one end to the middle of the other. Ventral margin slightly convex, the dorsal strongly so 3 , short and moderately broad with both sides nearly straight, while 4 is of moderate length. 
somewhat longer than 2, gradually tapering and with sides nearly straight. The paired papillae on its ventral surface are a little over two-thirds the way toward the tip and the claw at the distal margin is only moderately conspicuous. 5 is rather small, eurved, with the ventral side unusually concave and the tip slightly broadened and bearing the usual claws, which are here rather prominent. The inner side of 2 bears a spine near the middle, and the outer side two in the middle and nearer the dorsal margin; 3 has a spine at the basal margin on the inner side and one at the distal margin on the outer; 4 has in addition to the hairs on the papillae, two small ones on either side of the claw at the distal margin of the ventral surface; and 5 has a hair on the outer side a short distance from the base. Piersig (97) describes the hairs on the outer side of 2 as feathered hut I can discover no such on my specimens.

'The epimera are quite typical. 'The anterior groups are quadrilateral and the posterior rectangular with the spaces between them of eonsiderable width, especially in the female, in which sex the posterior groups are relatively shorter. The anterior groups have the anterior and posterior margins nearly equal, the outer a little shorter and the inner still shorter. I is nearly of equal breadth throughout and its inner end makes up the whole of the inner margin; II is triangular with both anterior and postcrior margins convex; while its inner end is prolonged into a short curved hook which turns backward and outward. III makes up only one-fourth of the length of the posterior group, which has a slightly concave anterior margin, a nearly straight inner margin, a convex posterior margin, and rounded angles.

The legs are of medium length, and rather slender, with the first pair not much thicker than the rest. I in the female is nearly five-sixtlis of the length of the body, II is about one-seventh longer than the body, III is sborter than II and about equal to the length of the body, while IV is more than a half longer than the body. In the male the legs are relatively somewhat longer. Of the individual segments, 4 is longest and the other's follow in the order $5,6,3,2,1$, except in IV where 5 is longest, and it and 6 both exceed 4. All the legs are abundantly supplied with hairs and spines, and many of them, especially on the middle segments of the anterior three legs and at the tip of IV 5 are long and almost like sivimming hairs. IV has the ventral surface of 4 and 5 thickly beset with spines of moderately length, and this pair of legs has, on the whole, more spines, but they are shorter than in the preceding pairs. The distal end of segment 6 on all the legs is broadened dorso-ventrally and receives in a groove in it the thus retractile claw. The claws possess two tips of which the proxinal one is slightly curved and meets the distal tip which is in line with the basal portion of the claw, at a right angle. The distal tip curves slightly for a short distance beyond the junction of the two, and then turns sharply ventrad so that its outer end is nearly parallel to the proximal tip.

Genital area flanked by two plates, each of which bears from 16 to 24 acetabula. The area in both sexes broader than long, each plate in the female with a thickened strip running from the groove at the genitai 
opening outward toward the acetabula, but not reaching them. The two plates in the male bear a few small spines and the margins next the groove are not thickened or produced. But in the female, these margins are thick, and produced outwardly in front of the genital opening to form two wide lips, which diverge at their tips. These lips each bear along their margins several spines, a small one anteriorly and two or three longer, stouter and somewhat curved ones about the middle. Behind the genital opening the lips are not so prominent and there is but a single longer and more slender spine.

MEASUREMENTS OF A FEMALE:

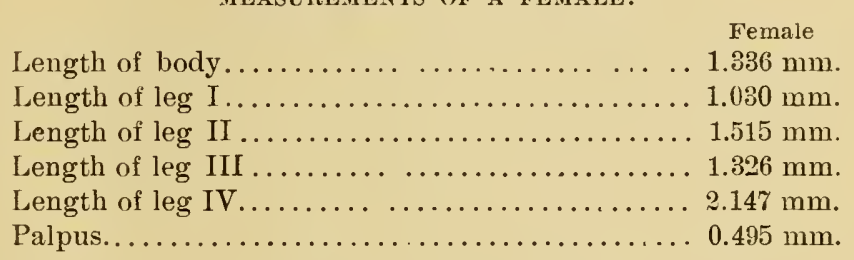

The number of previous records of the occurrence of this species in North America is such as to show it a very common and widely distributed form. Dana and Whelpley (36) found it at New Haven, Ct., in A. Anwiatilis Dillw, and in a second species of mussel which they incorrectly identified as Unio purpuratus Lam. Haldeman (42) seems to have collected it in A. Aluvictitis, U. radiatus and $U$. cariosus from the Susquehanna River, $\mathrm{Pa}$. Leidy (83) records it in A. Aluviatilis from Clarksboro, N. J., and Koenike (95b) from Canada, in Anodonta fragitis.

It was found to be common in the summer of 1893 at Lake St. Clair, in A. ovata, and also at Lansing, Mich., in the fall of the same year though in what mussels is uncertain.

In Northern Michigan it was equally abundant the next summer, being collected in A. subcylindracen and A. fortianct from Round Lake at Charlevoix; from the same and also from $A$. edentula and $A$. fragilis, from " 26 " and Twin Lakes in the vicinity of Charlevoix; and in A. subcylindrucea and $A$. fragitis from Intermediate Lake at Ellsworth, Mich.

At Grand Rapids, Mich., it is abundant and has been collected in numerous localities along Grand River, in $U$. pressus, M. marginata, M. rugosa, A. edentula, A. oveta, A. subcylindracea and $A$. footiana; from Reed's Lake in -1 . fragilis; from Rogue River, Kent County, in M. rugose, $A$. ovate and $A$. 
footiana; from Plaster Creek in A. ovata; and from the mill pond at Mill Creek in $A$. plana and $U$. pressus.

At White Lake, Muskegon County, Mich., it was collected during the past season in $A$. subgibbosa, A. subcylindacea, $A$. fontiana and M. complanata.

In Illinois, it has been found in $A$. corpulente and $A$. imbecilis from the Illinois river at Havana and in A. suborbiculata from Thompson's Lake near Havana. In Iowa it has been obtained in the Cedar River from $M$. megose at Mt. Vernon. In Nebraska the writer has collected it in $U$. subrostratus and A. grandis from pools near Lincoln; in $M$. complanata, $A$. planc and $A$. decore from Weeping Water Creek, Weeping Water; and in A. gromdis, A. plana and M. complanata from the Blue River at Milford.

From the material received from Chautanqua Lake, N. Y., it is apparently as common as in all other localities cited, and has been collected in $A$. plana and 1 . edentula

The record of collections shows that it is essentially an Anodonta parasite, though occuring in Margaritana and rarely in Unio.

\section{ATAX TUMIDUS WOLCOTT.}

Atax tumidus Wolcott, $98 ; 285$.

Very similar to $A$. ( $N$.) ingens in form and in size, the females of both showing a tendency to enormous distension when filled with eggs, in the relative length of the legs, and also in color, the internal structure of each as a rule giving no suggestion of the usual $Y$-shaped mark, but the color being a light brown with numerous fine white vermiculate lines, though specimens of $A$. tumidus have been found showing quite a well defined Y-mark. It was stated in the preliminary description of the species that it also agreed in the manner of depositing eggs, but the possibility of an error in this statement was changed to a probability by careful observations on this point during the past summer.

The species is, under normal conditions, one of the largest of the genus, the females measuring from 1.4 to $1.5 \mathrm{~mm}$. in length and when filled with eggs even 1.8 or $2.0 \mathrm{~mm}$., the males ranging from 1.10 to 1.25 $\mathrm{mm}$. The body is oval, broadened posteriorly, evenly rounded at both ends and uniformly arched, being also highest posteriorly.

Eyes small, black, and separated from each other by a considerable distance.

Maxillary shield similar to that of $A$. (N.) ingens, short and broad, with no ancoral process produced posteriorly, and with muscles attached to long curved processes projecting from the sides backward and upward. 
Mandibles like those of $A$. arcuata and $A$. ypsilophorus with the line separating the two portions carried backward on the ventral side toward the base, thus causing the distal to encroach on the basal portion. But here the encroachment is greater than in the other cases and the heary claw seems actually to spring from the side of the distal end of the ba-al portion.

Palpi comparatively stout, segment 4 especially noteworthy in thiat regard. The basal three segments are moderately thick but 4 is unusually so, being through most of its length nearly as thick as 3 , though narrowed somewhat before the papillae on the ventral surface is reached and firm that point diminishing rapidly in diameter till at the tip it is only onehalf as thick as at the base. This segment is also short, being not twice as long as 3 and its length only a little more than one-fifth greater than its cliameter toward its base. The paired papillae are very short while the third at the tip is quite rudimentary. Last segment rather long, strongly curved and blunt. Claws at the tip very small and inconspicuous.

Epimera resembling closely those of $A$. arcuata but relatively eren smaller.

Legs also resembling those of $A$. arcuata in general form but relatively heavier and differing in the fact that II is longer than III by about one-tenth. The swollen body of the present species is also longer in proportion to the length of the legs and only the last pair exceeds it in the male, while in the female none equal it, IV being a trifle shorter. The proportion between the segments resembles those in $A$. arcuata, as regards the relative length of 4 and 5 and the shortness of 6 . The distal segment is relatively stouter, and only slightly arcuate. The claws are characteristic, being short and thick with two hooks, the ventral of which is the heavier and somewhat the longer; it projects ventrally at a right angle to the base of the claw and the dorsal hook after continuing for a short distance in line with the base, also turns ventrad at a right angle. The tip of the segment is expanded and has two flattened leaf-like spines dorsally at the distal end which project beyond the claw.

Genital area.-Similar to that of $A$. arcuata in general form but absolutely larger and relatively broader; number of acetabula greater, in the male 34 to 35 , in the female 40 to 41 . In the male they corer most of the lateral plates which are reniform in shape, in the female while they reach the inner margin posteriorly, they leave about one-half the widith bare anteriorly: two lying against the outer margin exceed the others in size, as is the case in $A$. arcuata. 'l'he inner margin of each plate is prolonged into a long, flat pointed spine of which the anterior margin is convex, the posterior nearly straight, so that it is shaped something like a beak. Its width at the base is equal to one-fourth the length of the inner margin of the plate and it occupies the second fourth of the margin from the anterior end. The genital plates are thick and the margins rery heary, making a pronounced and quite broad border. 
MEASUREMENTS:

Male

Length of body .......... $1.170 \mathrm{~mm}$.

Length of leg I............ $0.724 \mathrm{~mm}$.

Length of leg II............. $0.994 \mathrm{~mm}$,

Length of leg III ............ $0.938 \mathrm{~mm}$.

Length of leg IV ............ $1.397 \mathrm{~mm}$.

Length of palpus............ $0.331 \mathrm{~mm}$.

I.ength of genital area....... $0.255 \mathrm{~mm}$.

Width of genital area........ $0.321 \mathrm{~mm}$.
Female

$1.660 \mathrm{~mm}$.

$0.949 \mathrm{~mm}$.

$1.372 \mathrm{~mm}$.

$1.255 \mathrm{~mm}$.

$1.612 \mathrm{~mm}$.

$0.372 \mathrm{~mm}$.

Types in the author's collection; co-types have been deposited in the collection of the Zoological Laboratory, University of Nebraska, in the Museum of Comparative Zoology of Harvard University, in the United States National Museum, and in the Kgl. Museum für Naturkunde in Berlin.

Atar tumidus was takell at Lake St. Clair in the summer of 1893, but only once, in Margaritana deltoides. At Ann Arbor, Mich., three specimens were found in the collection of the Zoological Department of the University of Michigan, from the Huron River, but no record had been made of the species of mussel. Two were collected at Lansing, Mich., but in what species of Unionidæ is uncertain.

It was only collected in North Michigan in Intermediate Lake at Ellsworth, August 9, 1894, from Anodonta fragitis and $A$. edentula-7 specimens being secured.

At Grand Rapids, Mich., it has been collected in Anodonta subcylindracea and Unio undulatus (once) from Grand River; in Anodonta ovate (?) from Plaster Creek; and in Anodonta subcylindracea from the mill-pond at Mill Creek, near Grand Rapids.

It thus has been taken only in Michigan and there but rarely, yet seems generally distributed through the state; it also seems to be restricted to Margaritana and Anodonita, and has proven most abundant in A. subcylindracea.

\section{ATAX (NAJADICOLA) INGENS (KOENIKE)}

Atax ingens Koenike, 95b; 219, Pl. III, f. 65 to 67.

Najadicola ingens Piersig, 97; 60.

$A$. $(N$.$) ingens is the largest of all our parasitic mites, especially if we$ consider the size of the gravid females, one of which has been collected measuring $6.0 \mathrm{~mm}$., though the average length of the females is from 2.25 to $2.50 \mathrm{~mm}$., and the males from 1.50 to $1.65 \mathrm{~mm}$. The body is broadly oval, evenly rounded at both ends, and much arched, highest posteriorly 
When filled with ripe eggs the femalc resembles a large swollen sac, with a cluster of short legs at one, and the more pointed end, which when the mite is in a dish, are quite incapable of serving for support or locomotion and the animal lies helplessly on.its back, unable to stir until some object which it can grasp is brought within reach, when its attempts to right itself and to escape from its uncomfortable situation are extremely laborious and in cases of great distension of the body, even utterly vain.

It possesses a different style of coloring from all other species except in the case of some specimens of $A$.tumidus, there being no $Y$-shaped lighter mark upon the back, but the whole body being of a lioney-yellow color, deepening to a yellowish-brown on the back, with numerous and irregularly distributed fine white vermiculate lines.

The eyes are reddish-brown, small and rather widely scparated. The maxillary shield is short and broad, and quite evenly rounded posteriorly, though on either side of the median line at the posterior extremity there is a small bulging of the outline due to a thickening of the margin of the shield. On each postero-lateral margin a little behind the middle is a curved chitinous process which runs laterally beneath the first epimeron.

The mandible is long and slender with an extreme breadth of a little over one-fifth the total length. It is thin and delicate, especially at the ventro-posterior angle where it is produced backward to a distance equal to one third the total length, forming a rectangular plate whlch is hol. lowed, producing a shallow mandibular furrow. The diameter of the basal joint is greatest just anterior to the posterior dorsal angle and grows gradually less till at the junction of the distal joint it is only about half as great. The distal joint is relatively small, with a claw which is broad, curved, indistinctly angled near the base, and sharply pointed. At the dorsal side of this claw is a thin flattened tapering chitinous process.

The palpi are moderately heavy and relatively short, averaging only about one-third the length of the body. The first segment is unusually long and much broader at its basal than at its distal end, which is not true of 2 , the distal margin of which is twice the breadth of the basal. The ventral margin of 2 is straight, the dorsal moderately convex; on the inner side are four spines, one near the middle at the dorsal side, a second a short distance ventrad and posteriad of this, and two others distad of the second, forming with it a row running to the middle of the distal margin. On the outer side of this segment a little proximad of the middle and toward the dorsal side are five small spines, enclosing an area which is a nearly regular pentagon. 3 is stout, its ventral margin nearly straight and more than half the slightly convex dorsal margin, and with a small spine on the inner side near the proximal margin. 4 is rather clumsy, nearly as thick at the distal as at the basal end, and bears two very inconspicuous papillae near the distal margin, and a small spur at the margin, on the ventral side. There is also a short, thick, blade-like spine on the inner side at the distal margin, and 5 has the usual three claws at the blunt tip. The palpi thus possess the general characters of those of other species of Atax, being peculiar in the number of spines on 2 and the one on the inner surface of 4 . 
The epimera cover only about one-third the whole ventral surface. The two groups of each side leave but a narrow interval betwcen them, but the space between those of opposite sides is wider, especially in the case of the anterior pair. The epimera of the male are relatively larger and closer together than in the female. I and II form a roughly triangular plate with a rounded inner angle, and from the inner end of the posterior margin of II a short, stout, curved process runs back beneath III. Of the plate formed by III and IV, III furnishes about one-third. This plate is longest externally, narrowed toward the median line and the inner end is rounded. All epimera are relatively thick.

Legs relatively short and stout, and the first pair slightly heavier than the rest. In females not distended with eggs and in males the first leg is a little over one-half the body length, II is a little longer than I, III is longer still and over threc-fifths the length of the body, and IV is longest but still less than the body-length. The proportions seem to be about the same in the two sexes. Of the individual segments, 5 is in all legs the longest, 6 about equal to it except in IV where 5 is slightly lengthened, and 4 next in length. The distal segments are nearly as thick as the proximal which gives the legs a rather clumsy appearance. Spines are comparatively very few and all short and stout; aside from this they are peculiar only in the fact that each segment except 1 and 6 , bears at the distal end, a group of from four to six of these short, stout spines. The claw is received in the end of 6 in a manner similar to that found in A. ypsilophorus and the distal end of the segment is slightly expanded. 'The claw is long, slender, strongly curved and slightly angled at twothirds the distance from the base, in the case of all but the first leg. In the case of $I$, the claw is stouter, shorter and evenly curved, but like all the rest simple and sharply pointed.

Genital area not at the end of the body but close behind the last epimera and so produced toward either side that the total breadth is about the same as the distance between the outer margins of the posterior groups of epimera, and approximately two-thirds the width of the body. Each plate has an outline roughly that of a right-angled triangle, the base of which corresponds to the anterior margin, the hypotenusc to the pusterior margin, while the short inner margin represents the altitude. The latter margin lies at a short distance from the genital cleft in the female, but in the male bounds it, and meeting the plate of the opposite side in front and behind, surrounds it. The anterior margin is nearly straight, the posterior slightly convex and the outer end rounded. The acetabula are numerous and vary in size, two toward the outer end of each plate being larger than any of the rest.

MEASUREMENTS:

Male

Length of body .............. $1.503 \mathrm{~mm}$.

Length of $\operatorname{leg}$ I.............. $0.826 \mathrm{~mm}$.

Length of leg II.............. $0.862 \mathrm{~mm}$.

Length of leg III. . . . . . . . . . . $0.943 \mathrm{~mm}$.

Length of $\operatorname{leg}$ IV ................

Length of palpus..............
Female

$2330 \mathrm{~mm}$.

$1.264 \mathrm{~mm}$.

$1.346 \mathrm{~mm}$.

$1.581 \mathrm{~mm}$.

$2.017 \mathrm{~mm}$.

$0.821 \mathrm{~mm}$. 
This species was first identified from a specimen collected at " 26 " Lake, near Charlevoix, Mich., from Anodonta fragilis, and another collected at Intermediate Lake, Ellsworth, Mich., also from $A$. fragilis. Koenike described it from that species and from Unio complanatus.

It seems to be found in both Unio and Anodonta, as at Grand Rapids, Mich., it has been collected in Unio gibbosus, $U$. ligamentinus and Anodonta footiana. In one specimen of A. footiana were 23 irregular masses of eggs, varying from 1.0 to $2.5 \mathrm{~mm}$. in diameter, and in varions stages of development, with one mite $2.0 \mathrm{~mm}$. long and another, a female full of eggs, $6.0 \mathrm{~mm}$. in length. At Long Lake, Kalamazoo, Mich., one male has been taken from $U$. luteolus. Only 16 specimens have been found altogether, so it seems, like $A$. tumidus, to be a rare species.

\section{SYNOPSIS OF THE SPECIES INCLUDED ABOVE.}

1. Genital field toward the end of the body and in general form more or less broadly oval or approximately circular; females with variously modified spines about the genital opening which assist in oviposition, the eggs being deposited singly in the gills,

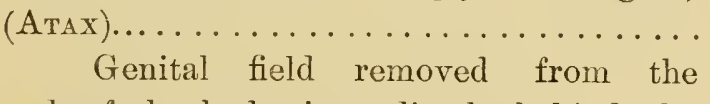
end of the body, immediately behind the last epimera and plates so extended transversely as to have the form of very low broad triangles, whose long bases extend from either side of the genital cleft a considerable part of the way toward the side of the body. No spines at genital opening, the eggs being laid in masses between the gills (Najadicola)...... $13 A .(N$.) ingens (Koen.)

2. Acetabula 6 on each side in two groups of three each....................... 3. 16 
Acetabula 5 on each side.............. 4 . Acetabula more than 6 on each side......... 10 .

3. First pair of legs thicker than the palpi, with movable spines set into the sides of deeply excavated conical papillae, and with claws simply bifid........ 1. A. crassipes (Miill.) First pair of legs not so thick as palpi, without movable spines, and with a broadly expanded pectinate claw..... 2. A. pectinatus mihi.

4. Legs very long, first pair thicker than palpi; body truncate posteriorly and with a prominent nipple-like papilla at either lateral posterior angle.......... 3. A. aculeatus Koen. Legs shorter and first pair not so thick as palpi; body evenly rounded or emarginate behind. . . . . . . . . . . . . . . . . . . . .

5. Last pair of legs modified and posterior margin of the body emarginate.............. 6 . Last pair of legs not modified and posterior margin of the body rounded............ 7 .

6. Modification consisting of a curved fourth segment on last pair of legs. Legs long and slender...... 4. A. intermedius Koen., male. Modification consisting of a thickening of the first four segments of the last pair of legs, and a shortening of the fifth, which bears two heavy spines, while the sixth is long and slender. All legs stouter and thicker......... 5. A. alnormipes milhi, male.

7. Genital plate of each side divided into two parts, with two and three acetabula respectively....................... 8 . Genital plate on each side not distinctly di-

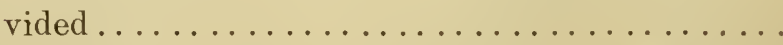

8. Claw with two hooks nearly equal in length, 4. A. intermedius Koen., female. 
Claw with a very small accessory tip on the convex side of the principal one.........

5. A. alnormipes mihi, female.

9. Last two acetabula placed side by side; claws bifid............... 8. A. fossulatus Koen. Acetabula placed in a continuous line; claws simple................ 9. A. stricta mihi.

10. Acetabula about nine on each side. Hind leg of male modified..... 6. A. indistinctus mihi. Acetabula 20 or more on each side........ 11 .

11. Distal segment of palpus expanded, quadrate and with two long curved claws. Body slightly emarginate in male, and legs, especially of females, with more or less serrate spines............. 7. A. serratus mihi. Distal segment of palpus slender, curved and ending in a blunt point armed with small claw-like spines. Body not emarginate behind and no serrate spines on the legs. 12.

12. First pair of legs not noticeably thicker than the rest; distal segment of the legs straight, and claws large and with two long equal hooks............. 11. A. ypsilophorus (Bonz). First pair of legs noticeably thicker than the rest and tapering from base to tip; distal segment slender, more or less arcuate and claws small and bifid................... 13.

13. Distal segment of legs decidedly arcuate; fourth segment of palpus tapering from base to apex. Maxillary shield with an ancoral process posteriorly......... 10. A. arcuata mihi. Distal segment of legs slightly arcuate; fourth segment of palpus swollen and nearly uniform in diameter from the base to the paired papillae on the ventral surface. Maxillary shield with no ancoral process posteriorly................ 12. A. tumidus mihi. 


\section{BIOLOGICAL CONSIDERATIONS.}

Most of these mites pass all their life stages within the limits of the mussel's shell, moving about over the surface of the mantle; a few, of which $A$. crassipes is an example, remain only till the last stages of development are reached and then leave the shelter of the mussel to pass the remainder of their life swimming freely about in the water. The eggs are deposited singly in the mantle and gills, rarely, as in $A .(N$.) ingens, in masses between the gills. The spines guarding the genital opening, by being inserted into the surface of the gill, probably assist in oviposition, either by holding the body firmly against the surface of the gill or mantle which is then pierced by the ovipositor, or by themselves piercing the surface, the ovipositor being protruded between them and the eggs deposited, rather more abundantly in the gills apparently, in the case of the Unio-dwellers, more numeronsly in the mantle by the Anodonta-parasites. The development of these eggs has been studied by Claparède (68) and others and five stages have been distinguished.

First, the egg stage, in which the embryo is surrounded by a firm outer membrane and a more delicate inner membrane -the "Zwischenhaut" of Claparède (68), the "Dotterhaut" of Kramer (80) or the "Apoderm" of Henking (82). The former, as development proceeds and the embryo increases in size, is ruptured, but the latter increases in size or is capable of distension and remains surrounding the embryo till the young mite is ready to emerge, when it is also burst open and the larva appears. Third, the first larval stage, in which the mite has but three pairs of legs, and which is very short. Fourth, the nymph stage, in which the larval legs are lost and a new set is developed beneath the old larval skin. Fifth, the second larval or sub-imago stage, in which the mite has four pairs of legs but in which it lacks still the perfect development of the sexual apparatus and the relative proportions belonging to the adult, those only being acquired when a final moult of the skin reveals the adult mite. It is not the intention in this paper to go into details as to this process, further than to note that the 
first two stages are passed in the substance of the gill, and the next apparently in the spaces between the plates of which the gill is composed. This stage is very short and the nymph is soon formed either in the spaces in the gills or outside them in the mucous over their surfaces. In the lacter case the iymphs accumulate in the mass of mucous at the exhalent aperature, and the same species of mite has been reared both from nymphs taken from the gills and from those sollected in the latter situation. During the second larval stage the mite is very active and moves freely about between mantle and gills. Generation follows generation in the mussel, the only check to the increase in number of mites being afforded by accidental escape or voluntary migration. The latter, as Kramer (91) observes, usually occurs during the second larval period when the body is smaller, the leg's longer, and the mites more active than later. When free from the ancestral mussel they no doubt swim here and there or clamber over the bottom with a chance of finding another mussel and effecting a lodgment therein. However, collections made with nets over beds of mussels have never, so far as the anthor's experience goes, furnished specimens of these migrating mites.

There seems to be no particular time of year when eggs are deposited as they are found throughout the season, but are apparently most numerous in the summer, while during early autumn the adult mites are most abundant. There also seems to be no one time at which the eggs from any one female mite are laid, but in the same shell and with but a single female, and in which other conditions lead to the inference that she laid all the eggs, they are found in various stages of development.

Lodgment is effected probably with different degrees of facility in different species of mussels. The swiftness of the current seems to have little effect in preventing it, if indeed it does not assist. In lakes with practically no current, collections show the following percentage of those infested, no other conditions being regarded, and all collections being made during August of different years: 
- In Lake St. Clair (Anchor Bay), of 251 mussels, 62 pe cent infested.

In Intermediate L., N. Mich., of 52 mussels, 65 per cent infested.

In Reed's Lake, Grand Rapids, Mich., of 96 mussels, 64.5 per cent infested.

While in Grand River, with a rapid current, collections at various points show:

Of 175 mussels, 62.33 per cent infested;

Of 73 mussels, 60.00 per cent infested;

Of 182 mussels, 90.50 per cent infested;

Of 85 mussels, 82.00 per cent infested.

These last two larger percentages were obtained during the past summer, when the percentage of infested mussels was unusually high. Indeed careful observations made during the summer in the attempt to secure more accurate data than had heretofore been obtained, as to the effect of different conditions, were rendered practically of no value from the fact that the percentage of mussels infested was so abnormally high as compared with other seasons that no accurate comparison could be made with former years and other localities. Still further observations are necessary and only general statements can be made in the discussion which follows.

The mussels which are most sensitive, most active in closing their shells, and whose shells close most tightly, seem to be more immune from the presence of parasites than those possessing less of these properties. The following figures have (p. 245) been selected with reference to such species of mussels as have been represented in the collections by a considerable number of specimens and illustrate different types as regards form.

If these $U$. occidens and $U$. ventricosus are thick, the valves meet at a considerable angle and not closely, and they are slower to close upon irritation. $U$. gibbosus, $U$. rectus and $U$. nasutus are long and thin, the valves meat at a small angle and tightly and they are more active. The other forms are intermediate in these respects. 


\begin{tabular}{lrrrr}
\multicolumn{1}{c}{ Mussel. } & $\begin{array}{r}\text { Collected } \\
\text { provious to } \\
1898 .\end{array}$ & $\begin{array}{c}\text { Per cent } \\
\text { infested. }\end{array}$ & $\begin{array}{c}\text { Collected } \\
\text { during } \\
1898 .\end{array}$ & $\begin{array}{r}\text { Per cent } \\
\text { infested. }\end{array}$ \\
$\left.\begin{array}{l}\text { Unio occidens } \\
\text { Unio rentricosus }\end{array}\right\}$ & 19 & 100.00 & 40 & 100.00 \\
$\begin{array}{l}\text { Unio luteolus } \\
\text { Unio ligamentinus }\end{array}$ & 60 & 70.00 & 33 & 85.00 \\
$\left.\begin{array}{l}\text { Unio plicatus } \\
\text { Unio undulatus }\end{array}\right\}$ & 57 & 63.00 & 75 & 96.00 \\
$\begin{array}{l}\text { Unio gibbosus } \\
\text { Unio rectus }\end{array}$ & 48 & 64.50 & 57 & 84.00 \\
Unio nasutus & 46 & 15.00 & 36 & 55.00 \\
\hline
\end{tabular}

This past summer, however, in the case of $U$. spatulatus and $U$. Novi-eboraci, which are very similar in size and form, an apparent exception to the rule was found; for of 46 specimens of $U$. spatulatus, 20 , or 43 per cent. were parasitized, while of 24 of the other species collected with U. spatulatus, all were infested. U. spatulatus has, to be sure, the ad. vantage in the angle at which the shells close and in activity, but hardly sufficient to lead one to infer the above result from simply a comparison of those characters. The mussels represented in the above table were all from Michigan, none from elsewhere being included, in order to avoid any necessity of allowing for a difference of locality. All were collected together along the Grand River at Grand Rapids, except $U$. nasutus which was from Lake St. Clair and U. luteolus which represented specimens from Lake St. Clair, Reed's Lake at Grand Rapids, and White Lake, Muskegon County, together with a few from North Michigan Lakes. Comparison of $U$. Tuteolus from the different localities showed practically a uniform percentage.

As between Anodontas and Unios, of 29 Anodontas taken previous to this year at the same localities as the above mentioned Unios, omitting $U$. luteolus, 17 or 58.5 per cent were infested; of those taken this summer 68 out of 74 or 72 per cent were infested. Anodontas taken with the $U$. luteolus enumerated above, previous to 1898 , showed a percentage of 72 per cent or 33 out of 46 , and during 1898 , of 95.5 per cent or 21 out of 22 . 
The size of the mussel seems to have little effect. No accurate records were made in regard to this fact previous to the past summer and for reasons stated above, these records are of little value in proving or disproving the fact of any connection between size and percentage of mussels infested. Generalizing from experience, in the absence of previous accurately recorded observations, it seems, however, that there is none.

The same is true of sex, which seems to affect in no degree the extent of parasitism, though it might be supposed that especially in the case of a gravid female entrance by the mite might be the more easily effected.

Records kept the past summer also as to depths at which the shell was buried and amount of vegetation on the bottom, furnish no satisfactory data. It has become evident that it is not an easy matter to collect facts in such form as to allow of a proper comparison of the importance of the various factors which determine the occurrence of parasitic mites in varions species of Unionidae and under different conditions. And it has also become evident that perfectly accurate statements, with the accumulation of the data necessary to furnish an adequate basis for them, will only be possible after years of careful observation. The author regrets that he has not the benefit of such in the preparation of this paper, but hopes that he may at some time in the not far distant future be able to report more fully upon this exceedingly interesting subject of research.

The maximum number of mites found in a single shell has occurred in the case of an Anodonta plana from a pool near Lincoln, Neb., opened in September,1895. In it were 15 Atax ypsitophorus and 406 A. intermedius-93 males and 313 females. The mussels collected in Nebraska, however, especially the Anodontas, have averaged more mites to the specimen than those collected in Michigan, thongh the percentage of those infested is about the same.

The presence of these mites seems to entail few, if any, consequences upon the host; though Garner (64) claims that their 
presence causes the growth of pearly prominences on the inside of the shell, and it is possible the irritation due to the presence of eggs in the mantle, might in some cases lead to this. The figures collected the past summer are not sufficient to allow of accurate statements being made. When the attempt is made to allow for the effect of age, of variation in form in the different species, and situation as affecting the probability of the entrance of foreign particles, the number of mussels examined does not furnish suficient data for definite conclusions. Other sources of uncertainty are added when it is considered that even if no mites are found in a mussel of considerable size the assumption that it never has contained any is entirely unwarranted, and when it is remembered that in case of infested musseis we have no means of knowing low long the mites have been there and whether or not sufficient time has elapsed for the demonstration of any effects on the host.

But upon the mites themselves the effect is more pronounced. Living in the gills during development and later in a slimy secretion, as they do, the tracheal system is less perfectly developed, in some cases becoming quite rudimentary. Yet they live for weeks in a vessel of water after removal from the mussel. Here the other effects of parasitism become apparent, especially if we compare free-living and parasitic species. The body of the parasitic forms is large and nore or less unwieldy, in the case of the females of $A$. tumidus and $A$. (N.) ingens so large, at times, as to incapacitate the mites for any morement, and the great thing lies on its back kicking its legs in the air utterly unable to eren hold itself right side up. The swimming powers are feeble and the animal sinks at once to the bottom where it clambers clumsily about, fortunate if any soft object allows it to obtain a foothold, at a great disadrantage if it be on a bottom too hard to allow its claws to penetrate. An apparent immunity from this effect of parasitism is seen in the case of $A$. aculeatus which, living as it does along the edge of the mantle and about the exhalent aperature, is more exposed to currents of water and retains the length of legs, small size of body and activity of movement almost un- 
impaired-indeed, it is quite as good a swimmer as $A$. crassipes. Aside from increase in size and unwieldiness of form, there is a lack of the bright coloring which makes the whole group such interesting objects of study. The method of oviposition leads finally to peculiarities of structure in connection with the female sexual organs, consisting of the spines abont the genital opening previously referred to. If kept for some time in a vessel of water cannibalism is never resorted to, no food is taken, and after weeks of starvation the mites finally die.

Haldeman (42) says they do not suffer from cold, as they are pretty active in water a few degrees above the freezing point; and he has found them moving about in a Unio, the outside layer of which was frozen. Nevertheless, they become torpid instantly, he says, if placed in freezing water, though the torpidity remains but a short time, if the temperature be gradually raised. As a rule, the migrations of the mussel from shallow to deep water and its habit of burying itself in mud during the winter, must make the temperature conditions within the shell very constant. Equally uniform is the supply of food, which is furnished to the animal with a minimum anount of exertion.

This stability of conditions under which the animal lives would lead us to expect little variation anong the mites and little is found. Cases occur, involving the number, size, form, etc., of acetabula on the genital plates, and to a slight degree the relative dimensions and character's of other parts. But in no case are these sufficient to cause any confusion amongst different species, even when these are found living together in the same mussel. Specific characters are well defined and constant, and with care in the examination of specimens and a knowledge of the characteristic structural features of each species, identification should be perfectly sure.

The strange thing is that under conditions so stable, so many species should occur. In this respect as compared with the European fauna ours seems remarkably rich, since we have now 13 recorded species of Atax as compared with 8 from all parts of the continent of Europe, and our list is likely to be increased by collections in the more distant parts of the coun- 
try, although those so far made cover seven states, from New York and Pennsylvania to Nebraska, and represent, all told, forty-one localities-2 2 in New York, 4 in Pennsylvania, 21 in Michigan, 1 in Wisconsin, 4 in Illinois, 2 in Iowa, and 7 in Nebraska. Material would be especially valuable from the South and from the Pacific Coast, and it is hoped this paper may be an incentive to investigators to take up the work of collecting Hydrachnidæ from those regions. Any material sent to the writer will be gratefully acknowledged, and if desired, labelled specimens returned; he will also gladly respond to any requests for information concerning the group.

Finally, the author would be doing an injustice both to those who have very generously assisted him and to his own sentiments of grateful appreciation, did he fail to acknowledge that assistance. To Dr. Richard Piersig of Leipzig, Germany, and to Prof. F. Koenike of Bremen, he is indebted for literature, and to Prof. Koenike also for specimens; each has been very generous and to the kindness of each he acknowledges his indebtedness. Naterial has been received from Mr. R. A. Johnson of Harvard University, Dr. R. H. Ward of Troy, N. Y., Mr. Jas. B. Shearer of Bay City, Mich., Mr. M. Ricker of Burlington, Ia., Prof. H. M. Kelly of Cornell College, Ia., Mr. O. D. Noble of Linwood, Neb., and Prof. H. B. Ward of the University of Nebraska, to each of whom the author extends his grateful acknowledgments. To Prof. Ward and to his former teacher, Prof. J. E. Reighard of the University of Michigan, he extends his thanks for many personal favors, and he also acknowledges his obligation to $\mathrm{Mr}$. Bryant Walker of Detroit, Mich., for assistance in the identification of the mussels collected. Finally, it is just and proper that he acknowledge the assistance of his wife in the routine of the examination of mussels collected. He shall feel that he has partially repaid his obligations to those mentioned if that which he has accomplished by their assistance shall meet with their approval. 


\section{BIBLIOGRAPHY.}

von BaEr, Carl Ernst.

27. Beiträge zur Kenntniss der neideren Thiere. Nova Acta phys-med. Acad. Caes. Leop.-Carolinae nat. cur., xiii, pt. 2, 523762. Bonnae, 1827.

Describes A.ypsilophorus as Hydrachna concharum.

Barrois ANd Moniez.

87. Catalogue des Hydrachnides rceneillies dans le nord de la France. Lille, 1887. $36 \mathrm{pp}$.

A. crassipes (Müll.), Cochleophorus spinipes (Müll.), C. vernalis (Müll.), A. ypsilophorus (Bonz), A. Bonzi (Clap.).

VAN BENEDEN, P.J.

48. Recherches sur. l'histoire naturelle et le déreloppement de l' Atax ypsilophora (Hydrachna concharum), etc. Bruxelles, 1848. (24 pp., 1 pl.).

The species studied was $A$. intermedius Koenike.

Berlese, ANt.

82. Acari, Myriopoda et Scorpiones hucusque in Italia reperta. 79 Fascicles and supplement. Padova, 1882-'96.

A. crassipes and "A. limosus Koch" (according to Piersig (96b), A. limosus Koch = Cochleophorus spinipes (Müll.).

Bessels, EMrL.

69. Bemerkungen über die in unseren Najaden schmarotzender Atax-Arten. Jahreshft. d. Ver. vaterl. Naturk. Württ. xxv, 1869, 146-152. Transl. by W. S. Dallas in Ann. and Mag. Nat. Hist. vii, $1871,55-59$.

Observations on developmeat, etc.

Bonz, Christoph. Gottlieb.

1783. Nora acta phys.-med. Acad. Caes. Leop.-Carolinae nat. cur., ete. Observatio x. vii, 52-53, Pl. I, f. 1--4. Norimbergae, 1783. Describes Acarus ypsilophorus.

Bruzelius, Ragnar Magnes.

54. Beslirifning öfver Hydrachniden, som förekomma inom Skàne. Akad. Abhandl. Lund, 1854.

Piestricted the genus to the limits since recognized: includes in observations $A$. crassipes and Cosh. spinipes.

NotE.-In this bibliography no mention has been made of articles which are simply records of occurrence. The different references are indicated by date, together with letter following when necessary. The designation given to each reference corresponds to that in the card catalogue of the author. which is believed to be complete, aud in which the sequence adopted is carefully chosen to indicate the order of publication. This designation is here retained to preserve a uniformity of cltation in this and other papers. 
Claparède, Euouard.

68. Studien an Acariden. Zeitschr: für wiss. Zool., xviii, pt. 4, $1868,446--480$.

Describes fully the development of $A$. ypsilophorus; describes $A$. Bonzi.

DADAY, EUG. V.

97. Die Fauna des Balatonsees. x. Wassermilben (Hydrachniden). Result wiss. Erfor'sch. Balatonsees ii, pt. 1, 195--205.

Describes Atax Hungaricus,=Cochleophorus spinipes (Müll.),juv.

98. Mikroskopische Süsswasserthiere aus Ceylon. Termézetr. Füzeter.,xxi, 1898, 123 pp., 55 text figures.

Describes Atax nodosus and $A$. singalensis, of which $A$. nodosus belongs to Cochleophorus.

DANA, (JAS. D.) AND Whelpley (JAS.).

36. On two American Species of the genus Hydrachna. Silliman's Amer. Jour. Sci. xxx, 1836, 354--359. Plate.

Describes Hydrachna formosa (= A. ypsilophorus) and H. pyriformis (spec. undet.).

DÙGES. ALF.

84. Naturaleza Mèxico, vi, 344.

Atax Alzatei, n. sp. (is a Curvipes).

Duges, Axtorne.

34. Recherches sur l'ordre des Acariens. Deuexième Memoire. Remarques sur la famille des Hydracnés. Ann. Sci. Nat. 2 me Série i, Zool., 1834, 144-174, Pl. x, xi.

Restricted genus Atax by separation of Diplodontus and Arrenurus, but as types of Atax gives Hydrachna histrionica Herm. (a Limnesia) and $H$. lutescens Herm. (a Piona).

Fabricius, ЈoH. Chr.

1792. Entomologia Systematica, etc. Hafniae, 1792-1794, 4 vols.

In vol. ii, pp. 398-406, gives all of Müller's species but $H$. grossipes, under the genus Trombidium.

05. Systema Antliatorum, etc. Brunsvigae, 1805.

Establishes genus Atax (=Hydrachna, Müller).

GARNER, R.

64. On a Parasitical Acarus of the Anodon. Rept. 33d Meet. Brit. Ass. Adv. Sci. Notices, 114.

A. ypsilophorus causes growth of pearly prominences on inside of shell.

Girod, Paul.

89. Recherches anatomiques sur les Hydrachnides parasites de l'Anodonte et de l'Unio, Atax ypsilophorus et Atax Bonzi. Bull. Soc. Zool. France, xiv, 1889, 107-110. Jour. Roy. Mic. Soc. Lond., 1889, $746-747$ (abstract).

93. Recherches sur la respiration des Hydrachnides parasites. Assoc. franç. Avanc. Sc. 22 Sess. Besançon, pt. 1, 248. 
HaLdeman, S. S.

42. On some American species of Hydrachnidae. Zoological Contributions, No. 1. Philadelphia, 1842.

Describes $9 \mathrm{spp}$. of mussel parasites under the "Genus? Unionicola" -U. oviformis, U. lactea (both $\doteq A$. ypsilophorus), $U$. personata, $U$. humerosa, U. symmetrica, U. proxima, U. lugbris, U. unicolor, $U$. reticulata (spp. undet.).

Haller, G.

81a. Die Hydrachniden der Schweiz. Mitth. der naturforsch. Gesin Bern. ii, 1881, 18-83, Pls. i-iv. Separate, Bern, 1882.

Synonymy and notes on A. crassipes, A. ypsilophorus, Coch. spinipes.

Harrington, Fletcher and Trrrell.

84. Report of the Entomological Branch for the season of $\mathbf{1 8 8 3 .}$ Ottawa Field Naturalists' Club. ii, 1884, 134-140.

Atax Bonzi (incorrect identification?) and $A$. ypsilophorus in America.

HENKING, H

82. Beiträge zur Anatomie, Entwicklungsgeshichte und Biologie ron Trombidium fuliginosum Herm. Zeit. f. wiss. zool, xxxvii, 1882, 553-663, Pls. xxxiv-xxx

IHERING, H. VON.

92. On the Geographical Distribution of Atax. Tr. N. Zealand Inst., $\mathrm{xxr}, 252-253$.

KocH, C. I.

35. Deutschlands Crustaceen, Myriapoden und Araclnniden. Regensbui"g, 1835-41 (40 parts). Also in Panzer's "Deutschlands Insekten," beginning with rart 132 .

37. Uebersicht des Arachnidensystems. Nürnberg, 1837-43 (4 parts).

In the former, simply describes species, in the latter arranges them systematically. Restricts Atax by separating from it the genera Nesaea, Piona, Hygrobates, Hydrochoreutes, Atractides, Acercus, Marica and Limnesia. Describes under Atax, A. crassipes (Müll.); A. truncatus, albidus, truncatellus, confluens, elegans (all $=A$. crassipes (Müll.)-Piersig, 96b); A. figuralis, diaphanus, lobatus (all =A. figuralis Koch-Piersig, 96b); $A$. spinipes (Müll.), freniger, falcatus, limosus, fastuosus, pictus, hyalinus, bifasciatus, furcula (all = Coch. spinipes (Müll.)Piersig, 96b); A. vernalis (Müll.) (Cochleophorus); A. grossipes (Müll.) (ident. ?) A. minimus Koch (ident. ?).

KOENIKE, F.

81a. Rerision von H. Lebert's Hydrachniden des Genfer Sces. Zeitschr. f. wiss. Zool., xxxv, pt. 4, 1881, 613-628.

81b. Vorläufige Notiz über die Bedeutung der "Steissdrüsen" bei Atax crassipes (Müll.). Zool. Anz. iv, 1881, 356-357. 
82. Ueber das Hydrachniden Genus Atax. Abh. naturw. Ver. Bremen, vii, 1882, 265-268.

90. Ein nener Bivalven-Parasit. 'Zool. Anz. xiii, 1890, 138-140. A. aculeatus, n. sp. from Germany.

90a. Eine Wassermilbe als Schneckenschmarotzer. Zool. Anz. xiii, 1890, 364-365.

A. Ampullariae, n. sp. from S. Brazil.

90b. Südamericanische anf Muschelthiere Schmarotzende AtaxSpecies. Zool. Anz, xiii, 1890, 424-427.

A. procurvipes, n. sp., A. perforatus, n. sp., $A$, rugosus, n. sp., A. Jheringi, n. sp. from S. Brazil.

91. Noch ein Südamericanischer Muschel-Atax. Zool. Anz. xiv, 1891, 15-16.

A. fissipes, n. sp. from S. Brazil.

91c. Kurzer Bericht über Nordamerikanische Hydrachniden. Zool. Anz., xir, 1891, pp. 256-258.

93. Die ron Herrn Dr. F. Stuhlmann in Ostafrica gesammelten Hydrachniden des Hamburger naturhistorischen Museum. Jahrb. wiss. Anst. Hamburg, x, 1893, 1-55, 3 Pls. Also separate.

Describes A. spinifer, n. sp., A. simulans, n. sp., (both Cochleophorus).

93c. Weitere Anmerkungen zu Piersig's Beiträgen zur Hydrachnidenkunde. Zool. Anz., xri, 1893, 460-464.

A. triangularis Piersig not valid-name preoccupied by Say, 1821.

95. Hydrachniden. Aus; Deutsch-Ost-Africa. Vol. iv, Die Thierwelt Ost-Africas, Wirbellose Thiere. Berlin, Geog. Verlagshdlg. Dietr. Reimer, 1895. 18 pp.

A. spinifer Koen., A. simulans Koen., A. spinipes (Müll.), A. pauciporus, n. sp., A.lynceus, n. sp., A. figuralis Koch (figs. only) (all Cochleophorus but the last two).

95a. Liste des Hydrachnides recueillies par la Dr. Théod. Barrois en Palestine, en «Syrie et en Egypte. Rev. Biol. Nord. Fr., vii, 1895, 139-147. Separate, Lille, 1895.

A. crassipes from Palestine.

95b. Nordamerikanische Hydrachniden. Abh. des naturwiss. Ver, zu Bremen, xiii, 1895, 167-226. Pls. i-iii. Also separate.

A. ypsilophorus (Bonz), C. vernalis (Müll.), A. ingens, n. sp., A. fossulatus n. sp., figs. of $A$. procurvipes Koen.

95̃d. Ueber bekannte und noue Wassermilben. Zool. Anz, xviii, 1895, 373-386, 389-392. 17 figs.

A. tricuspis, n. sp., (Germany), A. Schmackeri, n. sp. (China), A. verrucosus, n. sp. (Germany) (Cochleophorus), A. callosus, n. sp. (Germany) (also a Cochleophorus). 
96. Holtseinische Hydrachniden. Forsehungsber. aus der Biol. Station zu Plön., iv, 1896, 207-248. Pl.

A. crassipes (Màll.), A. limosus (Koch) Berlese, C. spinipes, (Müll), C. vernalis (Müll.), A. ypsilophorus (Bonz), A. intermedius Koen.

KRAMER, P.

75. Beiträge zur Naturgeschichte der Hydrachniden. Areh. f. Naturgeseh, xli, 1875, 263-332.

Describes $A$. coeruleus and A. loricatus, both of which $=$ Coch. spinipes.

77. Grundzüge zur Systematik der Milben. Arch. f. Naturgesch., xliii, 1877, 215-247.

Systematic.

80. Ueber die postembiryonale Entwicklung bei der Milbengattung Glyciphagus. Arch. f. Naturgesch., xlvi, 1880, 103-110.

KRENDOWSKY, M. E.

78. [Ueber die Erscheinung der Metamorphose bei Wassermieben]. (Russian). [Arbeiten der naturf. Ges. Charkow]. 66 pp. 2 pls. On metamorphosis, Refers to A. coeruleus Kram. (Cochl. spin. ipes.)

85. [Les Acariens d'eau donee (Hyclrachnides) de la Russie meridionalc]. (Russian). [Arb. Naturf. Ges. Charkow]. xviii, 1885. 209-358. 2 pls.

A. crussipes Müll., A. coeruleus Kram., (Coch. spinipes), A. ypsilophorus, v. Ben. (A. intermedius Koen.), A. corcharum v. Baer (A. ypsilophorus (Bonz), "A. Bonzi v. Ben."

Laboulbene, Alex.

51. Description de quelque Acariens et d'une Hydrachne. Ann. Soc. Ent. France, 2 me sèrie, ix, 1857.

His Hydrachna (Atax) viridana, aceording to Neuman (79) bclongs to Arrenurus.

LAMPERT, KARL.

93. Parasiten der Teichmuschel (Anodonta mutabilis Cless). Jahresheft Ver. raterl. Naturk. Württ. 1, 1893, 79-80.

A. intermedius Koen.

LEBERT, H.

79. Matériaux pour servir à l'étude de la faune profonde du lac Léman, par Dr. F. A. Forel. vi Série. Hydrachnides du Léman. Bull. Soc. Vaud. Sc. Natur., xvi, 1879, 327-377, 2 pls.

Refers to A.ypsilophorus, A. crassipes, and under "new genus, Neumania", describes $N$. nigra and $N$. alba (both=C. spinipes).

LEIDY, JOS.

83. On the reproduction and parasites of Anodonta fluviatilis. Proc. Acad. Nat. Sci. Phila.. 1883, 44-46.

A. ypsilophorus and $A$. Bonzi (?).

Müller, Otto Friedr.

1776. Zoologiae Danicae prodromus, etc. Hafniae, 1776. (274 pag.) 
1781. Hydrachnæ, quas in aquis Daniae palustribus, etc., Lipsiae, 1781. (88 pp., $11 \mathrm{pls}$.)

Describes 4 sp., Hydrachna crassipes (Atax), H. grossipes (ident. ?) H. spinipes (Cochleophorus), H. vernalis (Cochleophorus). Established Hydrachna to include all Water-mites.

Neunian, C. J.

80. Om Sveriges Hydrachnider, aus Konigl. Svenska Vet.-Akad. Hndlgr., xvii, (123 pp. 14 pls.). Separate, 1880.

Osborn (H.) AND UNDERWOOD (L.).

86. Preliminary List of the Species of Acarina of North America. Can. Ent., xviii, 1886, 4-12.

Refer to "A. humerosa" and "A. ypsilophorus," with the query after each, "where described ?"

Pfeiffer, CARL.

24. Naturgeschichte deutscher Land-und Süsswasser-Mollusken. (3 parts). Cassel, 1821; Weimar, 1824, '28.

Vol ii, p. 27-28, describes Atax ypsilophorus as Limnochares anodontae.

Piersig, Rich.

93a. Beiträge zur Hydrachnidenkunde, Zool. Anz., xvi, 1893. 393-399.

Desc. A. triangularis, n. sp. (Cochleophorus deltoides).

94b. Sachsens Wassermilben, Zool. Anz., xvii, 1894, 213-216.

Lists $A$. crassipes, $A$. figuralis, $A$. intermedius, A. Bonzi, $A$. ypsilophorus; proposes genus Cochleophorus and lists C. spinipes, C. deltoides, C. vernalis.

96. Beitrāge zur Kentniss der in Sachsen einheimischen Hydrachden-Formen. Leipsig, 1896. (71 pp.).

Chars. genera.-A. ypsilophorus (Bonz), A. intermedius Koen., A. Bonzi (Clap.), A. figuralis Koch, A. crassipes (Müll.), A. aculeatus Koel1., A. tricuspis Koen., C.spinipes (Müll.), C. deltoides Piersig, C. vernalis Koch., C. verrucosus (Koen.), C. callosus (Koen.)

97. Deutchlands Hydrachniden. Bibliotheca Zoologica, xxii. (5 parts issued.)

Includes the species listed in previons reference.

97a. Bemerkungen zur Hydrachnidenkunde. Zool. Anz., xx, 59-61. Proposes new genus Encentridophorus for A. spinifer Koen. from E. Africa, and Najadicola for $A$. ingens Koen. from Canada.

RATHKe, Jens.

1797. Skrivter af Naturhist. selsk., iv, pt. 1, 175. Pl. x. 1797. Say, Thomas.

Redescribes $A$. ypsilophorus as Trombidium notatum.

21. An account of the Arachnides of the United States. Jour. Acad, Nat. Sci., Phila., ii, 1821, 59-83. LeConte's Ed. of Writings, 1859, ii, 9-21.

Describes Hydrachna triangularis (prob. $=$ A. ypsilophorus].

17 
STOLL, OTto.

87. Hydrachnidae. Godman and Salvin's Biologia Centrali-Americana; Zool. Part lix, 1887, 9-15. Pls. vii-ix.

Desc. A. alticola, A. dentipalpis and A. septem-maculatus.

VAN VLEET, A. H.

96. Ueber die Athmungsweise der Hydrachniden. Zool. Anz., xix, $1896,505-507$.

Walckenaer [Chas. A. De] and Gervais [Paul].

44. Histoire Naturelle des Insectes. Aptères. Tom. iii; Paris; 1884. Neglecting all the advances made since the time of Dugés (34), enumerates under Atax 16 species belonging to several genera, among them A. crassipes Müll., A. grossipes Müll., A. spinipes Müll. (Cochleophorus), A. vernalis Müll. (Cochleophorus), A. furcula Koch and $A$. freniger Koch (=C. spinipes (Müll.)

Wolcott, R. H.

98. New American Species of the Genus Atax (Fab.) Bruz. Zool. Bull., i, 1898, 279-285.

\section{EXPLANATION OF PLATES.}

\section{PLATE XXVIII.}

Fig. 1. A. crassipes. Outer side, right palpus. Male. x 180.

Fig. 2. A. crassipes. Three basal segments of leg I. x 180.

Fig. 3. A. crassipes. Genital area of female. x 250 .

Fig. 4. A. aculeatus. Outer side, right palpus. Female. x 180.

Fig. 5. A. aculeatus. Posterior end of the body of a female, from the unmounted specimen. No attenipt has been made to mark the location of hairs, but proportions and relative positions of parts shown are correct. $\times 180$.

Fig. 6. A. aculeatus. Spine at the side of the genital opening of female. $\times 595$.

Fig. 7. A. pectinatus. Outer side, left palpus of female. $x 175$.

Fig. 8. A. pectinatus. Distal segment, leg I. Male. x 340.

Fig. 9. A. pectinatus. Mandible. x 175.

Fig. 10. A. pectinatus. Half of genital area of female. $\mathbf{x} 175$.

\section{PLATE XXIX.}

Fig. 11. A. intermedius. Outer side, left palpus of female. $\times 250$.

Fig. 12. A. intermedius. Distal joint, hind leg of female. $\times 180$.

Fig. 13. A. abnormipes. Outer side, left palpus of female. x 260.

Fig. 14. A. abnormipes. Anterior surface,rightleg IV of male. x 175.

Fig. 15. A. abnormipes. Claw of right leg 11 of male. $\times 540$.

Fig. 16. A. indistinctus. Outer side, right palpus of female. $\mathrm{x} 250$.

Fig. 17. A. indistinctus. Ventral surface, leg IV of male-segments 4,5 and $6 . \times 180$.

Fig. 18. A. serratus. Mandible of female. $\times 185$. 
PLA E XXVII

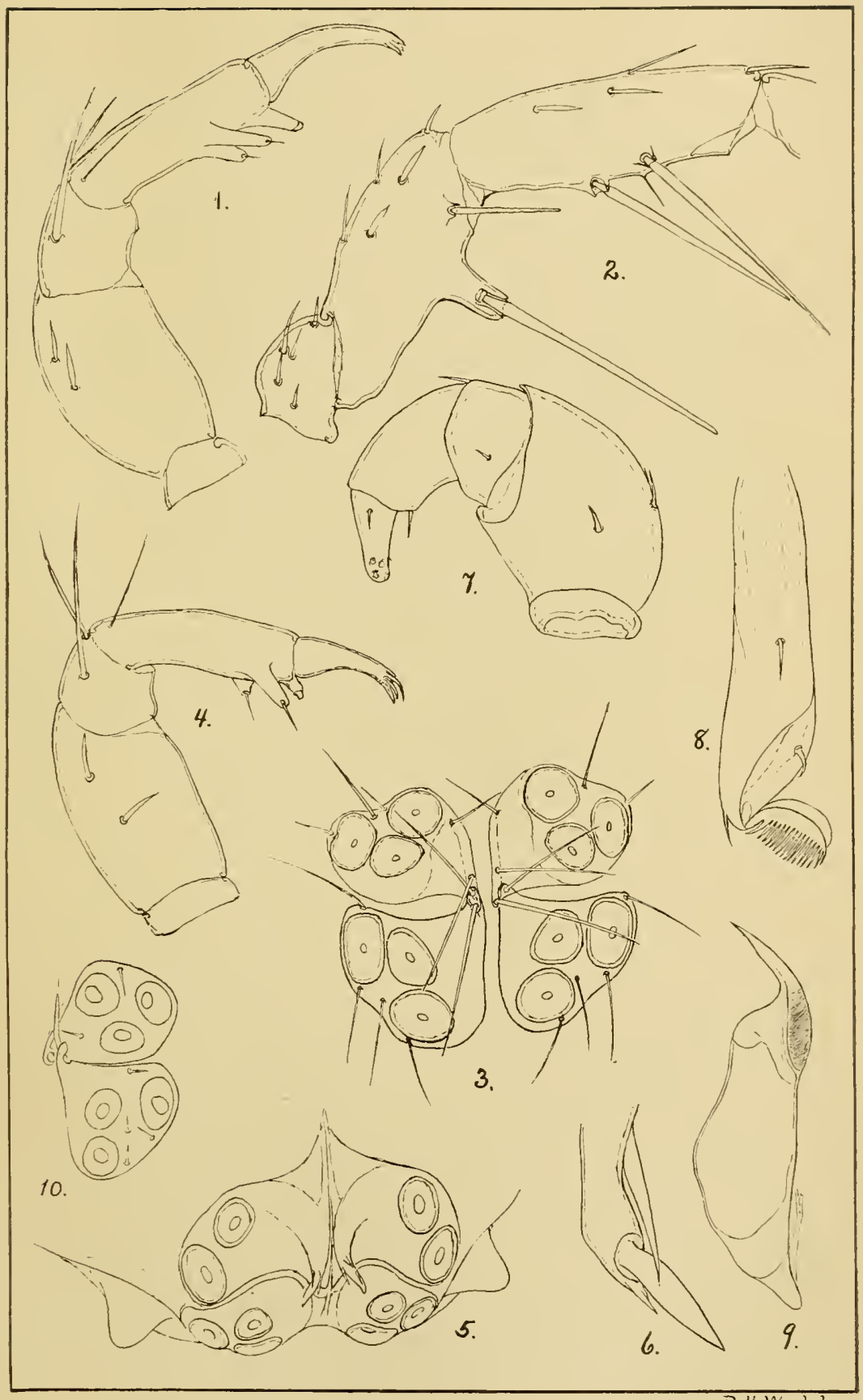

R.H.W. Lel. 

PLATE XXIX

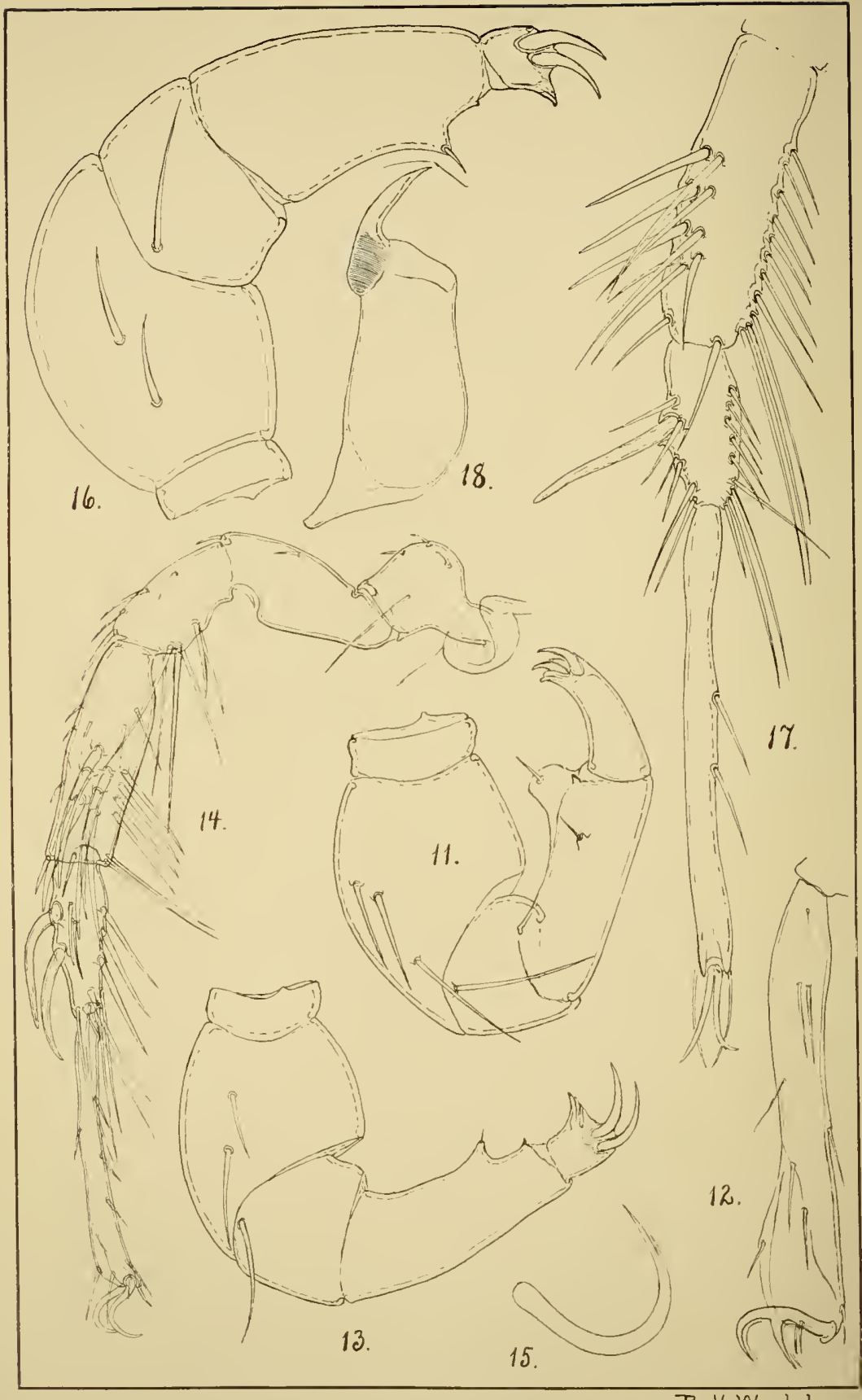

R.H.W del. 
PLATE $X X X$

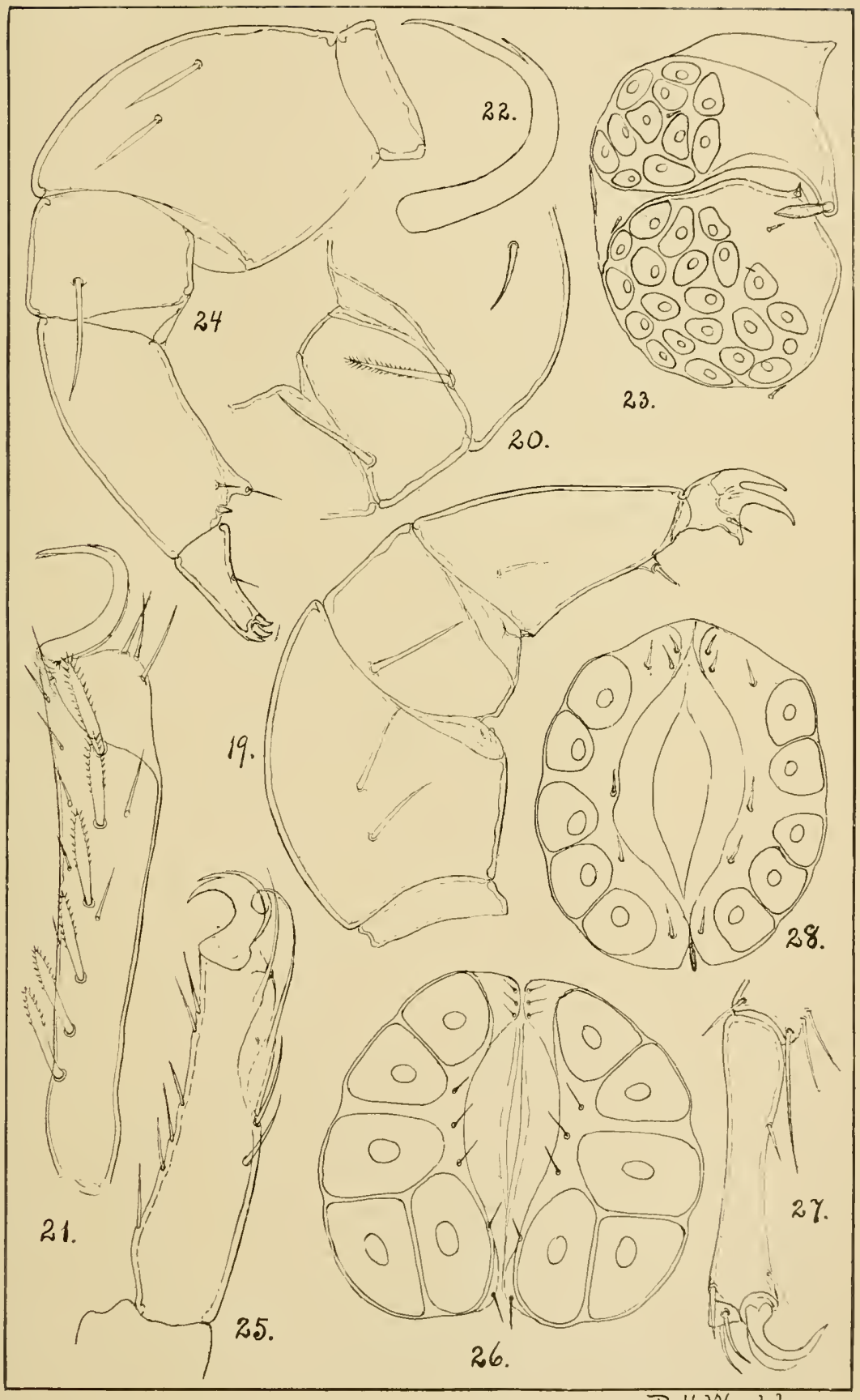

R.H.W. del. 


PLATE XXXI

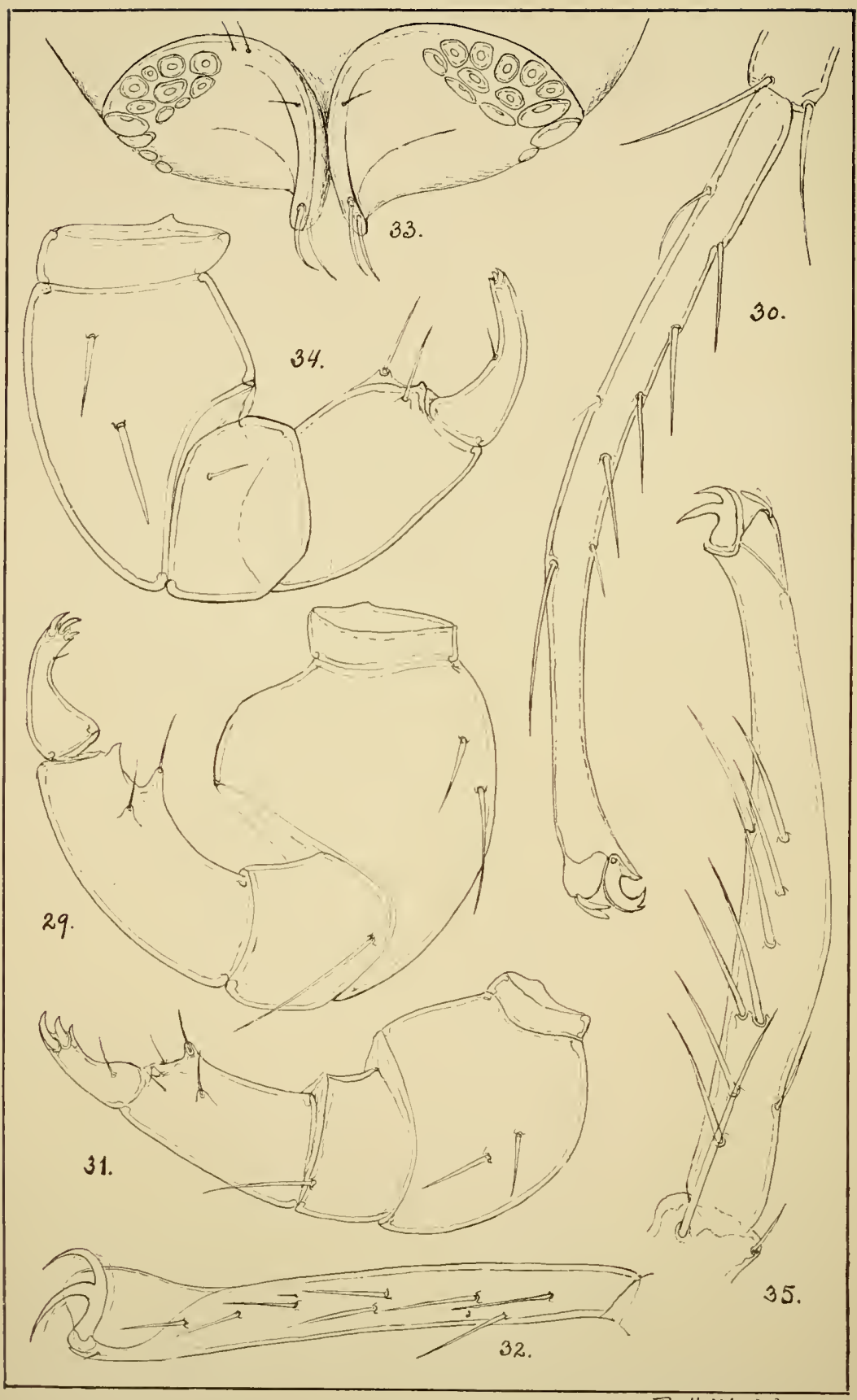

R.H.W. del. 


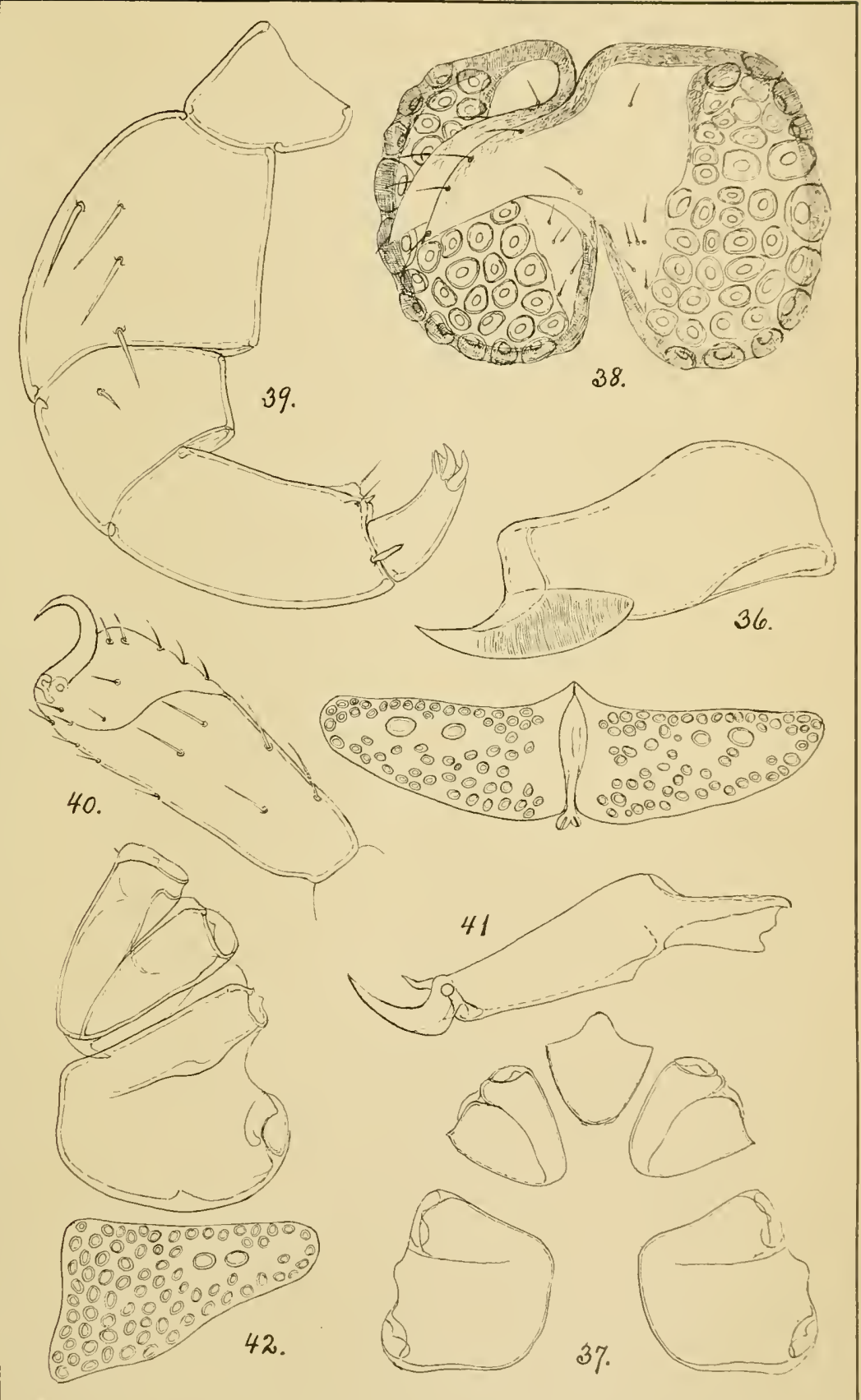

R. HW. del. 



\section{PLATE $X X X$.}

Fig. 19. A. serratus. Outer side, right palpus of female. $\mathrm{x} 170$.

Fig. 20. A. serratus. Inner side, part of left palpus. $\mathrm{x} 170$.

Fig. 21. A. serratus. Distal segment, right leg IV of female. x 185?

Fig. 22. A. serratus. Claw of right leg II. x 540 .

Fig. 23. A. serratus. One half of genital area of female. $\mathrm{x} 170$.

Fig. 24. A. fossulatus. Outer side left palpus of male. $\mathrm{x} 180$. x 250 .

Fig. 25. A. fossulatus. Distal segment of first pair of legs. Female.

Fig. 26. A. fossulatus. Genital area of male. x 180 .

Fig. 27. A. stricta. Distal segment of first pair of legs. Male. x 250 .

Fig. 28. A. structa. Genital area of male. $\mathrm{x} 250$.

\section{PLATE XXXI.}

Fig. 29. A. arcuata. Outer side, right palpus of female. x 250 .

Fig. 30. A. arcuata. Distal segment, last pair of legs, anterior surface. Female. x 190 .

Fig. 31. A. ypsilophorus. Outer side, right palpus of female. x 180.

Fig. 32. A. ypsilophorus. Posterior surface, distal segment, right leg IV. Female. x 180.

Fg. 33. A. ypsilophorus. Posterior end of body of female from ven. tral aspect. x 180 .

Fig. 34. A. tumidus. Outer side, left palpus of female. $\mathrm{x} 250$.

Fig. 35. A. tumidus. Anterior surface of distal segment, leg IV. Female. $\mathrm{x} 190$.

\section{PLATE XXXII.}

Fig. 36. A. tumidus. Mandible. $\mathrm{x} 180$.

Fig. 37. A.tumidus. Outline of the epimera and maxillary. shield of female. x 55 .

Fig. 38. A. tumidus. Genital area of female. x 180.

Fig. 39. $A .(N$.$) ingens. Inner side, palpus of male. \times 180$.

Eig. 40. A. (N.) ingens. Segment 6, first leg, anterior surface. Male. $\mathrm{x} 250$.

Fig. 41. A. (N.) ingens. Mandible. $\mathrm{x} 180$.

Fig. 42. A. (N.) ingens. Outline of epimera and genital plate of one side. Female. $\mathrm{x} 55$. The line represents the median line of the body.

Fig. 43. $A$. (N.) ingens. Genital area of male, penis exserted. $\mathrm{x} 76$. 




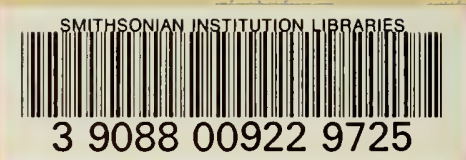

